\title{
Fuel-Cycle Energy and Emission Impacts of Ethanol-Diesel Blends in Urban Buses and Farming Tractors
}

\author{
Michael Wang, Chris Saricks, and Hanjie Lee \\ Center for Transportation Research \\ Argonne National Laboratory
}

\author{
(Final Report) \\ Prepared for \\ Illinois Department of Commerce and Community Affairs \\ Project Manager: David Loos
}

July 2003 


\section{Table of Contents}

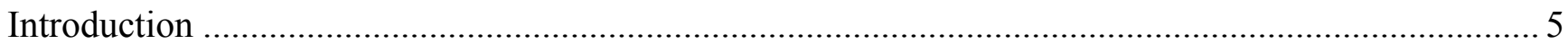

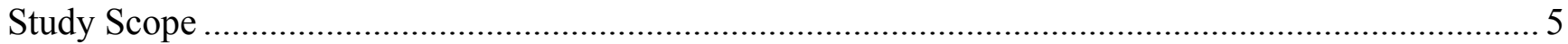

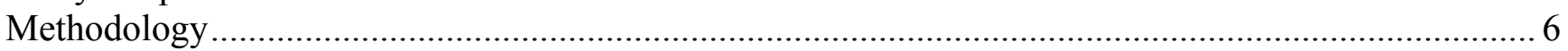

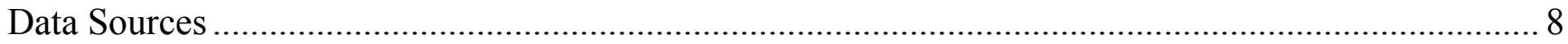

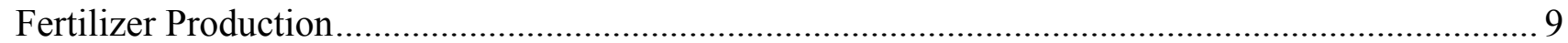

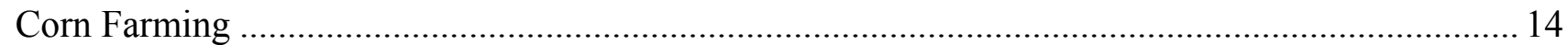

Nitrous Oxide Emissions from Nitrogen Fertilizer Applications in Corn Fields............................. 15

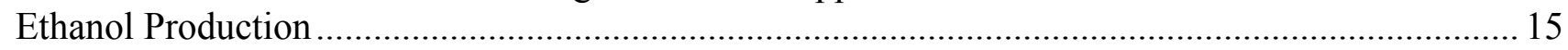

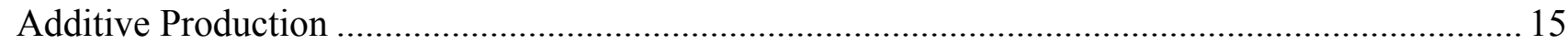

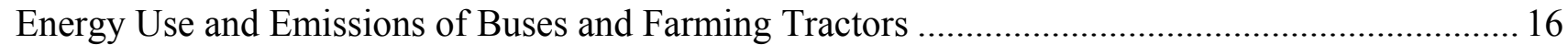

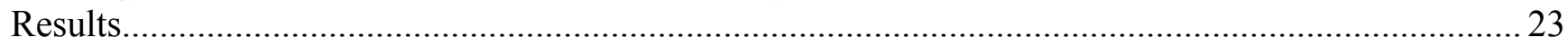

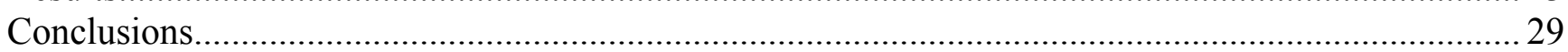

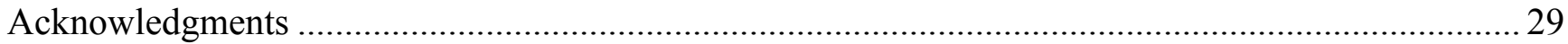

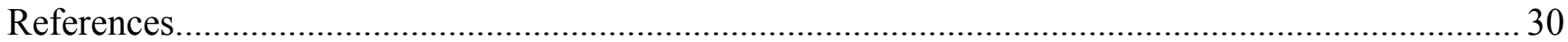

Appendix A: Energy Use and Emissions of Fertilizer Production ................................................. 34

Appendix B: Nitrous Oxide Emissions from Nitrogen Fertilizer Applications in Corn Fields ........... 39 


\section{Acronyms}

\begin{tabular}{|c|c|}
\hline 2WD & two-wheel drive \\
\hline 4WD & four-wheel drive \\
\hline $\mathrm{ADM}$ & Archer Daniels Midland \\
\hline AAPFCO & Association of American Plant Food Control Officials \\
\hline $\mathrm{CD}$ & conventional diesel \\
\hline $\mathrm{CH}_{4}$ & methane \\
\hline $\mathrm{CO}$ & carbon monoxide \\
\hline $\mathrm{CO}_{2}$ & carbon dioxide \\
\hline DCCA & Illinois Department of Commerce and Community Affairs \\
\hline DOE & U.S. Department of Energy \\
\hline E10 & $10 \%$ ethanol and $90 \%$ gasoline by volume \\
\hline ED & ethanol-diesel blend \\
\hline ED7.5 & $7.5 \%$ ethanol and $92.5 \%$ diesel by volume \\
\hline ED10 & $10 \%$ ethanol and $90 \%$ diesel by volume \\
\hline ED15 & $15 \%$ ethanol and $85 \%$ diesel by volume \\
\hline E-diesel & ethanol-diesel blend \\
\hline EFMA & European Fertilizer Manufacturers Association \\
\hline EPA & U.S. Environmental Protection Agency \\
\hline $\mathrm{FC}$ & fuel consumption \\
\hline GHG & greenhouse gases \\
\hline GREET & Greenhouse gases, Regulated Emissions, and Energy use in Transportation \\
\hline GWP & global warming potential \\
\hline $\mathrm{HC}$ & hydrocarbon \\
\hline HHV & higher heating value \\
\hline $\mathrm{HNO}_{3}$ & nitric acid \\
\hline $\mathrm{H}_{2} \mathrm{SO}_{4}$ & sulfuric acid \\
\hline IPCC & Intergovernmental Panel on Climate Change \\
\hline $\mathrm{K}_{2} \mathrm{O}$ & potassium oxide (potash) \\
\hline LHV & lower heating value \\
\hline LPG & liquefied petroleum gas \\
\hline LS & low-sulfur \\
\hline LSD & low-sulfur diesel \\
\hline MTBE & methyl tertiary butyl ether \\
\hline $\mathrm{N}$ & nitrogen \\
\hline NAFTA & North American Free Trade Association \\
\hline NG & natural gas \\
\hline $\mathrm{NH}_{3}$ & ammonia \\
\hline $\mathrm{N}_{2} \mathrm{O}$ & nitrous oxide \\
\hline $\mathrm{NO}_{\mathrm{x}}$ & nitrogen oxides \\
\hline OTT & Office of Transportation Technologies \\
\hline $\mathrm{P}_{5} \mathrm{O}_{2}$ & phosphorus oxide (phosphate) \\
\hline PM & particulate matter \\
\hline $\mathrm{PM}_{10}$ & particulate matter with diameter 10 microns or smaller \\
\hline PTW & pump-to-wheels \\
\hline RFS & renewable fuels standard \\
\hline
\end{tabular}




$\begin{array}{ll}\mathrm{S} & \text { sulfur } \\ \mathrm{SO}_{\mathrm{x}} & \text { sulfur oxides } \\ \mathrm{SwRI} & \text { Southwest Research Institute } \\ \text { TFI } & \text { The Fertilizer Institute } \\ \text { THC } & \text { total hydrocarbon } \\ \text { TOC } & \text { total organic compounds } \\ \text { USDA } & \text { U.S. Department of Agriculture } \\ \text { VOC } & \text { volatile organic compounds } \\ \text { PTW } & \text { pump-to-wheels } \\ \text { WTP } & \text { well-to-pump } \\ \text { WTW } & \text { well-to-wheels } \\ & \\ \text { Units of } & \text { Measure } \\ \mathrm{Btu} & \text { British thermal unit } \\ \mathrm{g} & \text { gram } \\ \text { gal } & \text { gallon } \\ \text { hp } & \text { horsepower } \\ \text { hr } & \text { hour } \\ \mathrm{kg} & \text { kilogram } \\ \mathrm{lb} & \text { pound } \\ \mathrm{mi} & \text { mile } \\ \mathrm{mmBtumillion} & \text { Btu } \\ \mathrm{ppm} & \text { parts per million } \\ \mathrm{rpm} & \text { revolutions per minute } \\ \mathrm{yr} & \text { year } \\ \end{array}$




\section{Introduction}

About 2.1 billion gallons of fuel ethanol was used in the United States in 2002, mainly in the form of gasoline blends containing up to $10 \%$ ethanol (E10). Ethanol use has the potential to increase in the U.S. blended gasoline market because methyl tertiary butyl ether (MTBE), formerly the most popular oxygenate blendstock, may be phased out owing to concerns about MTBE contamination of the water supply. Ethanol would remain the only viable near-term option as an oxygenate in reformulated gasoline production and to meet a potential federal renewable fuels standard (RFS) for transportation fuels. Ethanol may also be blended with additives (co-solvents) into diesel fuels for applications in which oxygenation may improve diesel engine emission performance.

Numerous studies have been conducted to evaluate the fuel-cycle energy and greenhouse gas (GHG) emission effects of ethanol-gasoline blends relative to those of gasoline for applications in sparkignition engine vehicles (see Wang et al. 1997; Wang et al. 1999; Levelton Engineering et al. 1999; Shapouri et al. 2002; Graboski 2002). Those studies did not address the energy and emission effects of ethanol-diesel (E-diesel or ED) blends relative to those of petroleum diesel fuel in diesel engine vehicles. The energy and emission effects of E-diesel could be very different from those of ethanolgasoline blends because (1) the energy use and emissions generated during diesel production (so-called "upstream" effects) are different from those generated during gasoline production; and (2) the energy and emission performance of E-diesel and petroleum diesel fuel in diesel compression-ignition engines differs from that of ethanol-gasoline blends in spark-ignition (Otto-cycle-type) engine vehicles.

The Illinois Department of Commerce and Community Affairs (DCCA) commissioned Argonne National Laboratory to conduct a full fuel-cycle analysis of the energy and emission effects of E-diesel blends relative to those of petroleum diesel when used in the types of diesel engines that will likely be targeted first in the marketplace. This report documents the results of our study. The draft report was delivered to DCCA in January 2003. This final report incorporates revisions by the sponsor and by Argonne.

\section{Study Scope}

In the past several years, test bench experiments and fleet demonstrations using E-diesel in diesel engines have been conducted in the United States and in other countries. Although both diesel passenger cars and diesel heavy trucks were tested with E-diesel, application of E-diesel in the United States will very likely be concentrated in subsets of the heavy vehicle fleet. So the present study does not encompass E-diesel use in diesel passenger cars, but focuses on urban transit buses and farming tractors, which are likely to be among the earliest commercial E-diesel applications. In past and current U.S. demonstration programs, buses and farming tractors operate on E-diesel blends. Besides the petroleum displacement advantage, use of E-diesel in urban buses is intended primarily to help reduce emissions of fine particulate matter $(\mathrm{PM})$ and oxides of nitrogen $\left(\mathrm{NO}_{\mathrm{x}}\right)$; $\mathrm{PM}$ has been identified as an important direct health threat and $\mathrm{NO}_{\mathrm{x}}$ as an important precursor of tropospheric ozone. The application of E-diesel in farming tractors is viewed by the agricultural community as a means to use an agriculture-based fuel for farming activities.

To this point, experiments have involved ethanol blended into diesel at proportions between $7.5 \% 5$ and $15 \%$ by volume (ED7.5 to ED15). In order to avoid phase separation, fuel additives are used in ED 
blends. Several vendors currently produce and supply proprietary additives for ethanol and diesel blending. For ED blends ranging from $7.5 \%$ to $15 \%$, the treat rate of additives ranges from about $1 \%$ to $1.5 \%$ by volume. In general, these rates are significantly lower than in earlier ED blends. We have included estimates of the energy use and emissions associated with additive production and distribution in our fuel-cycle analysis.

The U.S. Environmental Protection Agency (EPA) has adopted a low-sulfur (LS) diesel requirement that will begin to be phased in 2006. The new regulations will require that diesel fuel with a maximum sulfur (S) content of $15 \mathrm{ppm}$ (by weight) represent $100 \%$ of the diesel fuel supply for on-road vehicles by 2009. So LS diesel is assumed for urban bus applications in this study. By contrast, the off-road diesel used in farming tractors currently has very high sulfur content, often in excess of 3,000 ppm by weight. EPA intends to regulate the sulfur content of off-road diesel, but at this time, it is not clear what the mandated sulfur limit will be. We have assumed that the current on-road diesel, with an average 350-ppm sulfur content, will be used in future farming tractors. Table 1 lists the vehicle and fuel options evaluated in this study.

Table 1. Vehicle and Fuel Options Evaluated in This Study

\begin{tabular}{|l|l|l|}
\hline Fuel & Urban Buses & Farming Tractors \\
\hline Baseline fuel & 15-ppm-S diesel & $350-\mathrm{ppm}-\mathrm{S}$ diesel \\
\hline Ethanol diesel blends (by volume) & \begin{tabular}{|l|l|}
$10 \%$ ethanol, 89\% 15-ppm-S \\
diesel, and $1 \%$ additive
\end{tabular} & $\begin{array}{l}10 \% \text { ethanol, 89\% 350-ppm-S } \\
\text { diesel, and } 1 \% \text { additive }\end{array}$ \\
\hline ED10 & $\begin{array}{l}15 \% \text { ethanol, 83.5\% 15-ppm- } \\
\text { S diesel, and } 1.5 \% \text { additive }\end{array}$ & $\begin{array}{l}15 \% \text { ethanol, 83.5\% 350-ppm- } \\
\text { S diesel, and } 1.5 \% \text { additive }\end{array}$ \\
\hline
\end{tabular}

\section{Methodology}

Crop-based production of ethanol for blending with diesel fuel is distinctly different from petroleumbased production of diesel. Although ethanol itself is a renewable fuel, the production of corn and ethanol requires the use of fossil energy and generates GHG emissions. A complete evaluation of Ediesel vs. petroleum diesel requires a full fuel-cycle, or "well-to-wheels" (WTW), analysis. Argonne has conducted WTW analyses of ethanol/gasoline blends relative to gasoline (Wang et al. 1997; Wang et al. 1999). This study analyzes WTW energy and GHG emission effects of E-diesel vs. petroleum diesel by using a method identical to that used in the 1997 and 1999 studies, but with updated data on the energy use associated with fertilizer manufacture, corn farming, and ethanol production and on $\mathrm{N}_{2} \mathrm{O}$ emissions from cornfields.

A WTW analysis of a vehicle/fuel system covers all stages of the fuel cycle - from energy feedstock recovery (wells) to energy delivered at vehicle wheels (wheels). Since 1995, with funding from the U.S. Department of Energy's (DOE's) Office of Transportation Technologies (OTT), Argonne has been developing the Greenhouse gases, Regulated Emissions, and Energy use in Transportation (GREET) model as an analytical tool for use by researchers and practitioners to estimate WTW energy use and emissions associated with transportation fuels and advanced vehicle technologies. Argonne released the first version of the GREET model in June 1996 (Wang 1996). Since then, 6 
Argonne has released a series of GREET versions (Wang 1999; Wang 2001; General Motors Corporation et al. 2001a, b, c). The GREET model and associated documents are posted on Argonne's GREET website at http://greet.anl.gov.

Figure 1 presents the stages and activities covered in GREET's WTW simulations of vehicle/fuel systems. A WTW analysis includes the feedstock, fuel, and vehicle operation stages. The feedstock and fuel stages together are called "well-to-pump" (WTP) or "upstream" stages, and the vehicle operation stage is called the "pump-to-wheels" (PTW) or "downstream" stage. In GREET, WTW energy use and emission results are presented separately for each of the three stages shown in Figure 1.

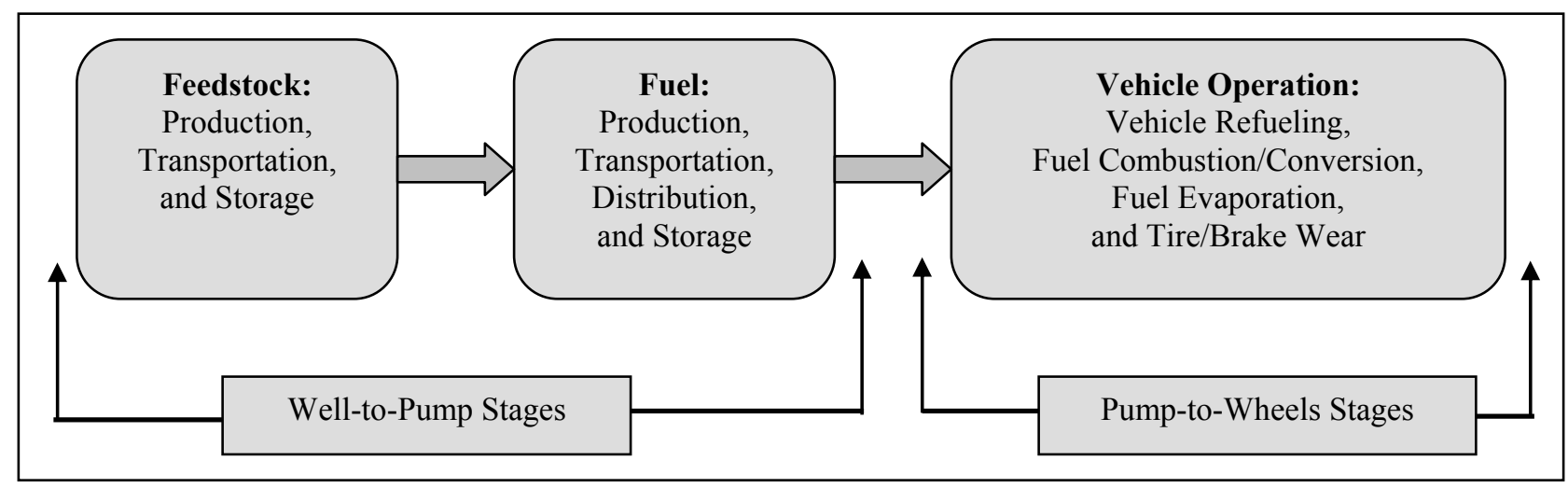

Figure 1. Well-to-Wheels Stages of Vehicle/Fuel Systems Covered in the GREET Model

In our WTW analyses, as in many other similar studies, we include energy use and emissions for operation stages only. That is, any activities included as part of an operation to make a fuel product are incorporated into our energy and emission calculations. Activities related to building infrastructure such as manufacturing plants, roads, and equipment - are not included. Contributions of infrastructure-related energy use and emissions to total WTW energy use and emissions are generally small.

Although the default version of the GREET model allows users to conduct single, point-based simulations (in which a single value is used for an input parameter), the new version of the GREET model - GREET 1.6 - is designed to allow users to also conduct stochastic simulations, in which the GREET model can generate energy and emission results with probability distribution functions. For the current study, stochastic simulations are conducted. To conduct such simulations with GREET 1.6, users need to have both Microsoft Excel ${ }^{\circledR}$ and Decisioneering's Crystal Ball ${ }^{\circledR}$ software.

GREET 1.6 was developed to simulate light-duty vehicles. In order to simulate buses and farming tractors, the model was reconfigured using vehicle fuel economy and emission inputs for buses and farming tractors. For bus simulations, results are generated on a per-mile-driven basis, the same as for light-duty vehicles. For farming tractor simulations, results are generated on a per-hour-of-operation basis; thus energy use and emissions for farming tractors are determined per hour of operation. The per-mile and per-hour energy and emission data for buses and farming tractors are input into GREET. 
The GREET model includes estimates of energy use, GHG emissions, and criteria pollutant emissions, as indicated below. This study addresses all of the following items.

1. Energy use

a. Total energy use (fossil and non fossil energy such as hydro-power and nuclear power)

b. Fossil energy use (petroleum, natural gas, and coal)

c. Petroleum use

2. GHG emissions (combined with global warming potentials [GWPs] to derive $\mathrm{CO}_{2}$-equivalent GHG emissions)
a. Carbon dioxide $\left(\mathrm{CO}_{2}\right)$
b. Methane $\left(\mathrm{CH}_{4}\right)$
c. Nitrous oxide $\left(\mathrm{N}_{2} \mathrm{O}\right)$

3. Emissions of criteria pollutants (separated into total and urban emissions)

a. Volatile organic compounds (VOC)

b. Carbon monoxide $(\mathrm{CO})$

c. Nitrogen oxides $\left(\mathrm{NO}_{\mathrm{x}}\right)$

d. Particulate matters (usually with diameter 10 microns or smaller, $\mathrm{PM}_{10}$ )

e. Sulfur oxides $\left(\mathrm{SO}_{\mathrm{x}}\right)$

Complete fuel-cycle energy impact analyses usually include total energy use, for which all energy sources — such as renewable energy and non-renewable energy (i.e., fossil energy) — are taken into account. Some analyses also address fossil energy impacts. In this case, fossil energy — including petroleum, natural gas, and coal - is taken into account. Because fossil energy resources are finite, analyses of fossil energy use reveal the impacts of energy resource depletion associated with a given vehicle/fuel system. This is especially important for ethanol; total energy impacts may not provide adequate information about it because the energy in ethanol comes from solar energy during crop growth, and use of solar energy per se for energy production is not a concern. Some studies also analyze petroleum displacement effects associated with vehicle/fuel systems. The petroleum displacement effect is an important issue for countries like the United States that rely on imported oil and intend to reduce that reliance.

The three GHGs are often combined together with their GWPs (Intergovernmental Panel on Climate Change [IPCC] 2001) to estimate $\mathrm{CO}_{2}$-equivalent GHG emissions. The GWPs of GHGs vary with the time horizon considered for determining them. With a time horizon of 100 years, GWPs are 1, 23, 296 for $\mathrm{CO}_{2}, \mathrm{CH}_{4}$, and $\mathrm{N}_{2} \mathrm{O}$, respectively (IPCC 2001); these values were used in our study.

\section{Data Sources}

GREET 1.6 contains input data regarding feedstock recovery, feedstock transportation, fuel production, and fuel transportation and distribution for both petroleum diesel and ethanol. Assumptions regarding petroleum diesel were reviewed and revised during a study that Argonne conducted for General Motors Corporation (General Motors Corporation et al. 2001a,b,c).

Assumptions regarding ethanol production pathways were first documented in Wang et al. (1997; 1999). During the current study, efforts were made to obtain new data on the energy use 8 associated with fertilizer production, corn farming, and ethanol production and on $\mathrm{N}_{2} \mathrm{O}$ emissions 
from agricultural soils. Revised assumptions for these activities are documented here. Assumptions regarding ethanol unchanged from the earlier studies can be found in Wang et al. (1997; 1999).

This study uses a probability-based simulation feature included in GREET 1.6. Probability-based parametric assumptions are required for these simulations, and wherever possible, were established for the key input parameters of this study.

\section{Fertilizer Production}

\section{Production and Consumption of Nitrogen Fertilizers}

Since 1999, the United States has become a net importer of nitrogen (N) fertilizer, as indicated by statistics from the Food and Agriculture Organization of the United Nations (1999). The increase in fertilizer imports is attributable to the abundant and relatively cheap new offshore sources, especially in the Commonwealth of Independent States, which have become available over the past decade. This development requires re-evaluation of GREET's treatment of $\mathrm{N}$-fertilizer production energy requirements by taking into account the shifts in fertilizer production between North America and production areas outside of North America.

Figure 2 presents the shares of U.S.-imported N-fertilizer by region for the period from July 2000 through June 2001. The chart was developed on the basis of data provided by the Economic Research Service of the U.S. Department of Agriculture (Taylor 2002). The chart reveals that NAFTA (North American Free Trade Association) onshore (Canada and Mexico) and NAFTA offshore (Central and South American countries) account for more than one half of the total tonnage of imported $\mathrm{N}$-fertilizer products (a slate comprising anhydrous ammonia, aqua ammonia, nitrogen solutions, solute ammonium nitrate, and solid urea). The grand total of nitrogen product imports is just over 14.6 million short tons (Table 2, extracted from Taylor [2002]). Total U.S. N-fertilizer consumption (as products) is about 24.4 million tons (Taylor 2002) — making the United States a net importer of $\mathrm{N}$-fertilizer products, with imports accounting for about $60 \%$ of the total $\mathrm{N}$-fertilizer consumption.

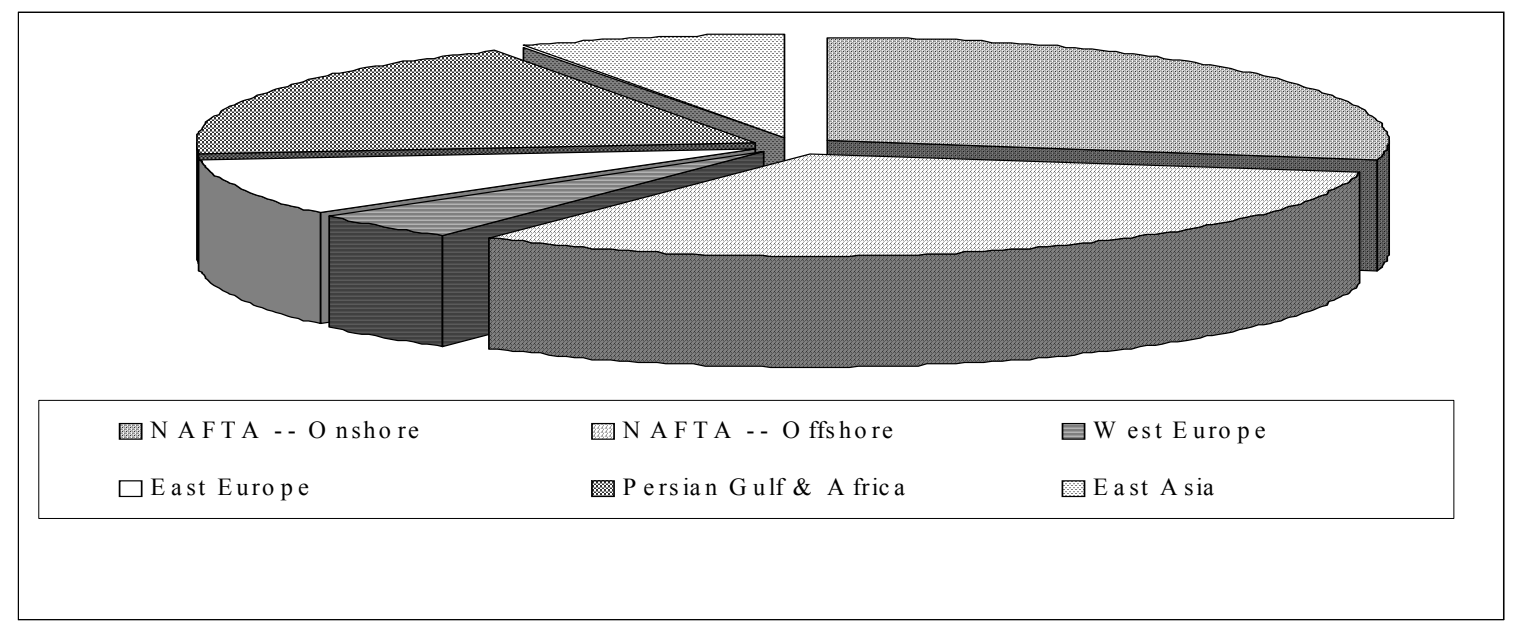

Figure 2. Shares of U.S. Imported Nitrogen Fertilizer by Region (based on Taylor 2002)

Table 2. U.S. N-Fertilizer Import Source Nations and Amounts for July 2000 to June 


\begin{tabular}{|c|c|c|c|c|c|c|c|}
\hline Source Nation & $\begin{array}{l}\text { Anhydrous } \\
\text { Ammonia }\end{array}$ & $\begin{array}{c}\text { Aqua } \\
\text { Ammonia }\end{array}$ & $\begin{array}{l}\text { Nitrogen } \\
\text { Solutions }\end{array}$ & $\begin{array}{c}\text { Ammonia } \\
\text { Nitrate } \\
\text { (solute) }\end{array}$ & $\begin{array}{c}\text { Urea } \\
\text { (solid) }\end{array}$ & Total & $\begin{array}{c}\text { Share of } \\
\text { Import }(\%)\end{array}$ \\
\hline NAFTA Onshore & 948,130 & 3,126 & 263,600 & 514,944 & $1,820,447$ & $3,550,247$ & 24.3 \\
\hline Canada & 901,481 & 3,126 & 263,600 & 514,944 & $1,820,412$ & $3,503,563$ & 24.0 \\
\hline Mexico & 46,649 & & & & 35 & 46,684 & 0.3 \\
\hline NAFTA Offshore & $3,491,997$ & & 3,054 & 847 & 538,542 & $4,034,440$ & 27.6 \\
\hline Trinidad \& Tobago & $3,228,091$ & & 3,054 & & 389,214 & $3,620,359$ & 24.8 \\
\hline Venezuela & 173,167 & & & & 74,140 & 247,307 & 1.7 \\
\hline Others & 90,739 & & & 847 & 75,188 & 166,774 & 1.1 \\
\hline West Europe & 12,263 & 864 & $\mathbf{1 0 9 , 5 7 1}$ & 170,773 & 259,738 & 553,209 & 3.8 \\
\hline Netherlands & 12,263 & & 48,250 & 100,843 & 82,804 & 244,160 & 1.7 \\
\hline Others & & 864 & 61,321 & 69,930 & 18,134 & 309,049 & 2.1 \\
\hline East Europe & 859,084 & & $1,731,421$ & 328,672 & 156,738 & $3,075,915$ & 21.1 \\
\hline Ukraine & 516,733 & & 405,424 & 150,359 & & $1,072,516$ & 7.3 \\
\hline Russia & 253,866 & & 563,518 & 96,171 & 10,484 & 924,039 & 6.3 \\
\hline Lithuania & & & 362,600 & 19,937 & & 382,537 & 2.6 \\
\hline Poland & & & 161,144 & & 36,033 & 197,177 & 1.4 \\
\hline Bulgaria & & & 88,453 & 19,854 & 75,331 & 183,638 & 1.3 \\
\hline Others & 88,485 & & 150,282 & 42,351 & 34,890 & 316,008 & 2.2 \\
\hline $\begin{array}{l}\text { Persian Gulf and } \\
\text { Africa }\end{array}$ & 91,304 & & 107,499 & 60,311 & $2,133,370$ & $2,392,484$ & 16.4 \\
\hline Saudi Arabia & 65,482 & & 13,228 & & 667,600 & 746,310 & 5.1 \\
\hline Qatar & & & & 222 & 442,245 & 442,467 & 3.0 \\
\hline Egypt & & & & 11,532 & 426,007 & 437,539 & 3.0 \\
\hline Bahrain & & & & 45 & 428,780 & 428,825 & 2.9 \\
\hline Others & 25,822 & & 94,271 & 48,512 & 168,738 & 337,343 & 2.3 \\
\hline East Asia & 226,322 & 1,008 & 23,133 & 515 & 752,948 & $1,003,926$ & 6.9 \\
\hline Indonesia & 217,200 & & & & 128,807 & 346,007 & 2.4 \\
\hline Malaysia & 6,301 & & 23,133 & & 298,387 & 327,821 & 2.2 \\
\hline China & & & & 1 & 210,345 & 210,346 & 1.4 \\
\hline Others & 2,821 & 1,008 & & 514 & 115,409 & 119,752 & 0.8 \\
\hline Total: products & $5,629,100$ & 4,998 & $2,238,278$ & $1,076,062$ & $5,661,783$ & $14,610,221$ & 100 \\
\hline Total: N nutrient & $4,615,863$ & 1,010 & 671,453 & 360,481 & $2,604,421$ & $8,253,228$ & \\
\hline
\end{tabular}

${ }^{a}$ Amounts are in short tons and are based on Taylor (2002).

Table 3 lists the consumption shares of major N-fertilizer types in the United States. As the table shows, there are eight types of N-fertilizer used on U.S. farms, but the three major types are anhydrous ammonia, nitrogen solutions, and urea. GREET, on the other hand, includes three fertilizer types for simulations: ammonia, urea, and ammonium nitrate. The eight types are combined into the three fertilizer types in the GREET model for our simulations (see footnote c to Table 3 ). 
Table 3. U.S. Nitrogen Fertilizer Consumption for Calendar Year $2000^{\mathrm{a}}$

\begin{tabular}{|l|c|c|c|}
\hline Fertilizer Type & $\begin{array}{c}\text { Product } \\
\text { Consumption }\end{array}$ & $\begin{array}{c}\text { Nutrient } \\
\text { Consumption }\end{array}$ & $\begin{array}{c}\text { Share by Type } \\
\mathbf{( \% )}^{\mathbf{c}}\end{array}$ \\
\hline Anhydrous Ammonia & $4,445,809$ & $3,645,564$ & 35.6 \\
\hline Aqua Ammonia & 338,026 & 68,309 & 0.7 \\
\hline Nitrogen Solutions & $10,424,279$ & $3,127,142$ & 30.5 \\
\hline Ammonium Nitrate & $1,698,355$ & 568,949 & 5.6 \\
\hline Urea & $4,697,642$ & $2,160,916$ & 21.1 \\
\hline Ammonium Sulfate & $1,121,318$ & 213,947 & 2.1 \\
\hline Ammonium Thiosulfate & 356,031 & 60,621 & 0.6 \\
\hline Other & $1,346,600$ & 403,980 & 3.9 \\
\hline Total & $\mathbf{2 4 , 4 2 8 , 0 6 0}$ & $\mathbf{1 0 , 2 4 9 , 4 3 0}$ & $\mathbf{1 0 0 . 0}$ \\
\hline
\end{tabular}

a Amounts are in short tons.

b From Association of American Plant Food Control Officials (AAPFCO) and The Fertilizer Institute (2001).

${ }^{\mathrm{c}}$ The shares are based on nitrogen nutrient consumption. While there are eight types of N-fertilizer that are used on U.S. farms, the GREET model has energy and emission simulations for three types: ammonia, urea, and ammonium nitrate. For GREET simulations, the shares of anhydrous ammonia, aqua ammonia, nitrogen solutions, and other are combined together as the share of ammonia (70.7\%), and the shares of ammonium nitrate, ammonium sulfate, and ammonium thiosulfate are combined together as the share of ammonium nitrate $(8.3 \%)$.

\section{Feedstock Use, Energy Use, and Emissions for Fertilizer Production}

In our analysis, we include estimates of energy use and emissions of nitrogen, phosphate, and potassium fertilizers - the three major fertilizer types used for corn farming. Among the three types, nitrogen fertilizer is used most intensively for corn faming, and it is the most energy intensive one to produce.

Our estimates of feedstock and process fuel use during the production of ammonia, urea, ammonium nitrate, and phosphoric acid are discussed in Appendix A and summarized in Table 4. On the basis of the results presented in Appendix A, we developed two cases (low energy use and high energy use) for production of ammonia, urea, nitric acid, and phosphoric acid (Table 4). The two cases are derived primarily from reports prepared by the U.S. Department of Energy (DOE) and The Fertilizer Institute (TFI) (DOE 2000; TFI 2001). The European Fertilizer Manufacturers Association (EFMA) also reports energy use and emissions associated with fertilizer production (EFMA 1995; 2000a, b, c, d). DOE's total fuel use value is close to that reported by EFMA (no data for shares of process fuels and electricity are available from EFMA), and thus no separate estimate is developed from the EFMA data. For production of phosphoric acid, TFI and EFMA data are averaged because of their similarity.

The GREET model estimates energy use and emissions associated with transporting fertilizers and feedstocks from their origin to their destination by specifying transportation logistics such as transportation distance and transportation mode. The GREET estimated energy use for transporting fertilizer from plants to farms is about $274 \mathrm{Btu}$ per $\mathrm{lb}$ of fertilizer. 
Table 4. Summary of Feedstock Use, Energy Use, and Emissions for Fertilizer Production (based on results presented in Appendix A)

\begin{tabular}{|c|c|c|c|c|c|c|c|c|c|c|c|c|}
\hline & & Ammo & $\left(\mathrm{NH}_{3}\right)$ & & & $\begin{array}{r}\text { Nitr } \\
\text { (H }\end{array}$ & $\begin{array}{l}\text { Acid } \\
\left.D_{3}\right)\end{array}$ & $\begin{array}{c}\text { Ammonium } \\
\text { Nitrate }\end{array}$ & $\begin{array}{c}\text { Sulfuric } \\
\text { Acid }\end{array}$ & $\begin{array}{c}\text { Phosphoric } \\
\text { Rock }\end{array}$ & Phosp & ic Acid \\
\hline \multirow{6}{*}{$\begin{array}{l}\text { Feedstock } \\
\text { (tons/ton } \\
\text { product) }\end{array}$} & & Low & High & Low & High & Low & High & & & & Low & High \\
\hline & Natural Gas & 0.46 & 0.46 & & & & & & & & & \\
\hline & $\mathrm{NH}_{3}$ & & & 0.567 & 0.567 & 0.405 & 0.405 & 0.213 & & & & \\
\hline & $\mathrm{HNO}_{3}$ & & & & & & & 0.788 & & & & \\
\hline & $\mathrm{H}_{2} \mathrm{SO}_{4}$ & & & & & & & & & & 2.674 & 2.674 \\
\hline & Phos. rock & & & & & & & & & & 3.525 & 3.525 \\
\hline \multirow{3}{*}{$\begin{array}{l}\text { Process fuel }^{\mathrm{a}} \\
\text { (mmBtu/ton) }\end{array}$} & Electricity & 1.838 & 0.389 & 0.212 & 0.046 & 0.006 & 0.006 & 0.242 & 0.0635 & 0.245 & 0.557 & 0.371 \\
\hline & Other fuels ${ }^{b}$ & 3.556 & 11.371 & 1.464 & 2.816 & 0.526 & 0.526 & 0.440 & 0.0445 & 0.000 & 1.546 & 6.800 \\
\hline & Total & 5.394 & 11.760 & 1.676 & 2.862 & 0.532 & 0.532 & 0.682 & 0.108 & 0.245 & 2.103 & 7.171 \\
\hline \multirow{5}{*}{$\begin{array}{c}\text { Total } \\
\text { energy } \\
\text { (mmBtu/ } \\
\text { ton) }\end{array}$} & Electricity & 1.838 & 0.389 & & & & & & & & 0.557 & 0.371 \\
\hline & Other fuels & 3.556 & 11.371 & & & & & & & & 1.546 & 6.800 \\
\hline & Energy in & & & & & & & & & & & \\
\hline & feedstock & 18.906 & 18.906 & & & & & & & & 1.160 & 1.160 \\
\hline & Total & 24.300 & 30.666 & & & & & & & & 3.263 & 8.331 \\
\hline \multirow{6}{*}{$\begin{array}{l}\text { Process } \\
\text { emissions }^{\mathrm{c}} \\
(\mathrm{g} / \text { ton })\end{array}$} & VOC & $4,285.8$ & $4,285.8$ & & & & & & & & & \\
\hline & $\mathrm{CO}$ & 27.240 & $7,173.2$ & & & & & & & & & \\
\hline & NOx & & & & & 549.34 & 998.80 & & & & & \\
\hline & $\mathrm{PM}_{10}$ & & & 53.118 & 147.55 & & & $1,058.3$ & & & & \\
\hline & SOx & 9.08 & 26.332 & & & & & & 18,160 & & & \\
\hline & $\mathrm{N}_{2} \mathrm{O}$ & & & & & 1,648 & 14,183 & & & & & \\
\hline
\end{tabular}

${ }^{\text {a }}$ These values represent process fuel use for the individual process only. All values for energy calculations in this study are based on lower heating values (LHVs) of fuels.

${ }^{\mathrm{b}}$ Mainly natural gas.

${ }^{\mathrm{c}}$ These values are emissions in addition to the emissions associated from combustion of process fuels. $\mathrm{CO}_{2}$ emissions for fertilizer manufacture are calculated by using a mass balance approach inside the GREET model; the difference in carbon between input items and output products becomes $\mathrm{CO}_{2}$ emissions. 
Table 5. Parametric Assumptions for Fertilizer Production in the GREET Model (per ton of product, based on Table 4)

\begin{tabular}{|c|c|c|c|c|c|c|c|c|c|c|c|c|c|c|c|}
\hline & \multicolumn{3}{|c|}{ Ammonia } & \multicolumn{3}{|c|}{ Nitric Acid } & \multicolumn{3}{|c|}{ Urea } & \multirow{2}{*}{$\begin{array}{c}\text { Ammonium } \\
\text { Nitrate }\end{array}$} & \multirow{2}{*}{$\begin{array}{l}\text { Sulf. } \\
\text { Acid }\end{array}$} & \multirow{2}{*}{$\begin{array}{l}\text { Phosp. } \\
\text { Rock }\end{array}$} & \multicolumn{3}{|c|}{ Phosphoric Acid } \\
\hline & Low & Mean & High & Low & Mean & High & Low & Mean & High & & & & Low & Mean & High \\
\hline Total energy input $(\mathrm{mmBtu})^{\mathrm{a}}$ & 24.30 & 27.49 & 30.67 & & 0.532 & & 1.676 & 2.269 & 2.862 & 0.682 & 0.108 & 0.245 & 2.103 & 4.637 & 7.171 \\
\hline Total NG input (mmBtu) & 22.46 & 26.37 & 30.28 & & 0.526 & & 1.464 & 2.140 & 2.816 & 0.440 & 0.0445 & 0.000 & 1.546 & 4.173 & 6.800 \\
\hline Electricity input $(\mathrm{mmBtu})^{\mathrm{c}}$ & 1.84 & 1.12 & 0.39 & & 0.006 & & 0.212 & 0.129 & 0.046 & 0.242 & 0.0635 & 0.245 & 0.557 & 0.464 & 0.371 \\
\hline NG process fuel input (mmBtu) & $3.55^{\mathrm{d}}$ & $7.46^{\mathrm{d}}$ & $11.37^{\mathrm{d}}$ & & 0.526 & & 1.464 & 2.140 & 2.816 & 0.440 & 0.0445 & 0.000 & 1.546 & 4.173 & 6.800 \\
\hline $\begin{array}{l}\text { NG process fuel share of total } \\
\text { NG energy input }(\%)\end{array}$ & 15.8 & 28.3 & 37.5 & & 100 & & 100 & 100 & 100 & 100 & 100 & & 100 & 100 & 100 \\
\hline Ammonia (tons) & & & & & 0.405 & & & 0.567 & & 0.213 & & & & & \\
\hline Nitric acid (tons) & & & & & & & & & & 0.788 & & & & & \\
\hline Sulfuric acid (tons) & & & & & & & & & & & & & & 2.674 & \\
\hline Phosphoric rock (tons) & & & & & & & & & & & & & & 3.525 & \\
\hline \multicolumn{16}{|l|}{ Processing emissions $(\mathrm{g})$} \\
\hline VOC & & 4,286 & & & & & & & & & & & & & \\
\hline $\mathrm{CO}$ & 27.240 & 3600.2 & 7,173 & & & & & & & & & & & & \\
\hline $\mathrm{NO}_{\mathrm{x}}$ & & & & 549.3 & 774.1 & 998.8 & & & & & & & & & \\
\hline $\mathrm{PM}_{10}$ & & & & & & & 53.118 & 100.33 & 147.55 & $1,058.3$ & & & & & \\
\hline $\mathrm{SO}_{\mathrm{x}}$ & & 26.33 & & & & & & & & & 18,160 & & & & \\
\hline $\mathrm{N}_{2} \mathrm{O}$ & & & & 1,648 & 7,916 & 14,183 & & & & & & & & & \\
\hline
\end{tabular}

a The total energy input here includes energy in feedstocks and in process fuels.

b Although some other process fuels besides NG are used in fertilizer plants, we assume here that all process fuels are NG.

${ }^{c}$ Electricity input here is calculated as the difference between the total energy input and the NG input. Energy losses during electricity generation are not included in this table. They are taken into account inside the GREET model and in the final energy and emission results for ethanol.

${ }^{\mathrm{d}} \mathrm{NG}$ input as the process fuel for ammonia production is calculated from total NG input subtracted by NG input as feedstock for ammonia production ( 0.46 tons of $\mathrm{NG}$, or $18.91 \mathrm{mmBtu}$, of NG per ton of ammonia). 


\section{Corn Farming}

Shapouri et al. of the U.S. Department of Agriculture (USDA) (Shapouri et al. 2002) recently developed updated estimates of the energy requirements for corn farming. They used data from the 1996 Agricultural Resource Management Survey (formerly the Farm Costs and Returns Survey) to determine corn farming energy use and chemical application. The data were for nine key Midwest corn-producing states that produce $80 \%$ of total U.S. corn. Table 6 presents energy and chemical use values from Shapouri et al. that are used in GREET simulations in this study. Of the total farming energy use, $46 \%$ is from diesel fuels, $20 \%$ from gasoline, $15 \%$ from liquefied petroleum gas (LPG), 12\% from NG, and 6\% from electricity. These energy sources power tractors, irrigation equipment, crop-drying machinery on corn farms, and other activities.

Table 6. Corn Farming Energy and Chemicals Use (per bushel of corn produced)

\begin{tabular}{|l|c|c|c|}
\hline & Minimum $^{\text {a }}$ & Mean $^{\text {a }}$ & Maximum $^{\text {a }}$ \\
\hline Farming Energy (Btu, LHV) & 19,963 & 23,288 & 34,224 \\
\hline Share of Farming Energy by Fuel Type (\%) \\
\hline Diesel & & 38.3 & \\
\hline Gasoline & & 12.3 & \\
\hline LPG & & 18.8 & \\
\hline NG & & 21.5 & \\
\hline Electricity & & 9.0 & \\
\hline N fertilizer: $\mathrm{N}_{(\mathrm{g})}$ & 305 & 470 & 577 \\
\hline P fertilizer: $\mathrm{P}_{5} \mathrm{O}_{2}(\mathrm{~g})$ & 88 & 175 & 273 \\
\hline K fertilizer: $\mathrm{K}_{2} \mathrm{O}(\mathrm{g})$ & 18 & 215 & 391 \\
\hline
\end{tabular}

a The minimum and maximum values are based on the range of the results of the nine Midwestern states (Illinois, Indiana, Iowa, Minnesota, Nebraska, Ohio, Michigan, South Dakota, and Wisconsin). The mean values are the nine-state average values.

${ }^{b}$ The farming energy use values presented in Shapouri et al. are in higher heating values (HHVs). The values presented here are the LHVs that were used in this study. The farming energy values here include use of diesel fuel, gasoline, LPG, NG, electricity, custom work, lime, and seeds.

In addition to the energy use rates presented in Table 6, about 6,000 Btu of energy is consumed to transport each bushel of corn from farms to ethanol plants. This value is calculated inside GREET as a function of truck fuel economy, truck payload, and transportation distance.

Besides the three fertilizer types listed in Table 6, our analysis includes energy and emissions associated with the manufacture of herbicides and insecticides (see Wang et al. 1997). 


\section{Nitrous Oxide Emissions from Nitrogen Fertilizer Applications in Corn Fields}

Appendix B documents our efforts to obtain new data on cornfield $\mathrm{N}_{2} \mathrm{O}$ emissions. On the basis of data presented there and considering the potential $\mathrm{N}$-fertilizer-induced $\mathrm{N}_{2} \mathrm{O}$ emissions outside of growing seasons and a small increase in indirect $\mathrm{N}_{2} \mathrm{O}$ emissions from nitrate, we have increased $\mathrm{N}_{2} \mathrm{O}$ emissions for our new "point estimate" from $1.5 \%$ to $2.0 \%$, with a range of $1 \%$ to $3 \%$.

\section{Ethanol Production}

Both wet and dry milling ethanol plants produce fuel ethanol in the United States. As of December 2002, the U.S. total ethanol production capacity is about 2.704 billion gal/yr. Of this, 1.108 billion gal are produced in wet mill plants, the rest in dry mill plants (Shaw 2002). That is, wet mill plants account for about $41 \%$ of the total capacity, with the remaining $59 \%$ being dry mill capacity. The large share of dry milling capacity results from the fact that recently built ethanol plants are all dry mills - a trend that will continue in the future because dry mills can be smaller and require less capital investment than wet mills and because co-products (such as glucose from wet mills) are not bringing returns commensurate with production costs. Thus, we assume that by 2010 - the target year for our analysis - 70\% of total U.S. ethanol production will be in dry mills, and the remaining $30 \%$ will be in wet mills.

The USDA study (Shapouri et al. 2002) surveyed ethanol plants to determine their energy use. Revised energy use values for ethanol production have been estimated for GREET. They are as follows, based on the USDA survey results: 36,119 Btu/gal (LHV) of ethanol for dry mills (89.7\% of which is energy provided by NG and coal, and the remaining $10.3 \%$ is energy provided by electricity), and 45,954 Btu/gal (LHV) for wet mills (all provided by NG and coal). Note that Shapouri et al. report HHVs in all cases, while GREET uses LHVs for simulations.

The GREET model estimates energy use and emissions associated with transporting ethanol from ethanol plants to fuel refueling stations by specifying transportation logistics such as transportation distance and transportation mode. The GREET-estimated energy use for transporting ethanol from plants to refueling stations is about $1,480 \mathrm{Btu} / \mathrm{gal}$ of ethanol.

\section{Additive Production}

Several manufacturers of chemical solvents and blending agents supply the additive needed to combine diesel fuel with ethanol in a manner that precludes blend instability or separation of the two components. Early E-diesel blends used co-solvent additives of up to 5\% by volume, but more recently, the "treat rate" for co-solvents has been closer to $1 \%$ to $2 \%$. We contacted several additive suppliers that are currently active in E-diesel blending to obtain insights regarding the production energy requirements and energy density per unit volume of their products. All of those who responded agreed on two points:

(1) The heating value of one or more of the available E-diesel additives is approximately equal to that of conventional gasoline. 
(2) Process energy for additive manufacture is supplied by NG and grid electricity at rates (energy consumption and GHG generation per output Btu) that are comparable to those for the products of a state-of-the-art petroleum refinery.

Specific responses to questions about energy balances were graciously supplied by two additive manufacturers. We examined the information provided by the two additive manufacturers and determined that there could be significant variation in production processes for additives. We believe that additives can be produced along two general pathways: one in petroleum refineries where they are produced as a co-product with other refinery products, and the other in a chemical plant where they are produced as one of the designated products. For the petroleum refinery pathway, we assumed an energy efficiency of $85 \%$ for additive production - the efficiency for gasoline production applied in GREET. For the chemical plant pathway, we assumed an energy efficiency of $68 \%$. This efficiency is consistent with the efficiency of many chemical processes, such as production of methanol, dimethyl ether, and hydrogen. In GREET simulations, we applied a distribution function with minimum, average, and maximum efficiencies of $68 \%, 76.5 \%$, and $85 \%$, respectively. We acknowledge, based on data provided by manufacturers, that the current batch production process for the chemical plant pathway could have an efficiency as low as $50 \%$. However, if E-diesel is ever to have any significant market share, additive production will be likely to move from batch to continuous production; otherwise, cost-competitiveness for the finished fuel will be very unlikely.

On the basis of information provided by additive manufacturers, we used a product density of $7.5 \mathrm{lb} / \mathrm{gal}$ for additives and a heating value comparable to that of gasoline (approximately $115,000 \mathrm{Btu} / \mathrm{gal}$ ). We further applied a process fuel split (of $80 \% \mathrm{NG}, 20 \%$ electricity) in GREET simulations.

\section{Energy Use and Emissions of Buses and Farming Tractors}

E-diesel stakeholders generally agree that the near- and medium-term thrust for introducing Ediesel into the fuel market will target (1) agricultural equipment in grain-growing regions, and (2) transit buses in central and western urban areas that are currently designated as nonattainment areas for ambient ozone or, when designated, for fine particulate standards. An ED10 (10\% ethanol) product containing, on average, $1 \%$ co-solvent additive (by volume) can fuel agricultural equipment and, to a lesser extent, the medium and light heavy-duty farm trucks. Transit buses will be fueled by an ED15 (15\% ethanol, $1.5 \%$ additive) blend because the higher ethanol content has been associated with improved effectiveness in reducing combustion-related fine particle emissions - a major urban health problem. Our purpose is to identify criteria pollutant and $\mathrm{CO}_{2}$ emission rates currently associated with these vehicle classes and express them as (or enable their conversion to) units consistent with the GREET methodology.

\section{Agricultural Tractors and Trucks}

A testing program using an ED10 blend to fuel agricultural tractors is underway through a cooperative agreement among the State of Illinois, the University of Illinois at UrbanaChampaign, members of the E-diesel Consortium, and John Deere, Inc. (Hansen et al. 2001). 
Thus, performance data are being developed using John Deere agricultural equipment, and we have applied information specific to this equipment (from the John Deere web site) in our calculations.

For Deere tractors, the fuel consumption rate at rated engine speed (rpm) appears to be an approximately monotonic function of rated horsepower, regardless of whether the tractor is twowheel drive (2WD) or four-wheel drive (4WD) (Table 7). Utility tractors start at about $50 \mathrm{hp}$, and the largest agricultural tractors are rated at $450 \mathrm{hp}$. We selected a value of $365 \mathrm{hp}$, corresponding to the midpoint of 4WD units but incorporating both top 2WD units and maximum 4WD unit power requirements if a 70-hp variation (plus or minus) about this midpoint is assumed. 
Table 7. Fuel Consumption Rates and Power Output of John Deere Tractors ${ }^{\mathrm{a}}$

\begin{tabular}{|c|c|c|}
\hline \multirow[t]{2}{*}{ Tractor Type } & \multicolumn{2}{|c|}{ Power Output } \\
\hline & $\mathrm{mmBtu} / \mathrm{hr}$ & hp-h/mmBtu \\
\hline \multicolumn{3}{|l|}{ 2WD Tractors } \\
\hline \multicolumn{3}{|l|}{5320 Utility Tractor: $55 \mathrm{hp}$} \\
\hline Power takeoff at $2,400 \mathrm{rpm}$ & 0.440 & 126.66 \\
\hline Maximum power takeoff at $1,900 \mathrm{rpm}$ & 0.410 & 142.53 \\
\hline \multicolumn{3}{|l|}{ 6310 Tractor: $80 \mathrm{hp}$} \\
\hline Power takeoff at $2,300 \mathrm{rpm}$ & 0.655 & 124.48 \\
\hline Standard power takeoff at 2,200 rpm & 0.640 & 128.37 \\
\hline Maximum engine power at $1,900 \mathrm{rpm}$ & 0.630 & 140.04 \\
\hline \multicolumn{3}{|l|}{7610 Tractor: $120 \mathrm{hp}$} \\
\hline Power takeoff at $2,100 \mathrm{rpm}$ & 0.915 & 132.10 \\
\hline Standard power takeoff at $2,100 \mathrm{rpm}$ & 0.915 & 132.10 \\
\hline Maximum engine power at $2,100 \mathrm{rpm}$ & 0.900 & 140.66 \\
\hline \multicolumn{3}{|l|}{8420 Tractor: $235 \mathrm{hp}$} \\
\hline Power takeoff at $2,200 \mathrm{rpm}$ & 1.695 & 139.65 \\
\hline Standard power takeoff at 2,200 rpm & 1.695 & 139.65 \\
\hline Maximum power takeoff at $2,000 \mathrm{rpm}$ & 1.850 & 148.13 \\
\hline Maximum engine power at 2,199 rpm & 1.685 & 120.67 \\
\hline \multicolumn{3}{|l|}{ 4WD Tractors } \\
\hline \multicolumn{3}{|l|}{9200 Tractor: $310 \mathrm{hp}$} \\
\hline Power takeoff at 2,100 rpm & 1.970 & 134.83 \\
\hline Standard power takeoff at $1,900 \mathrm{rpm}$ & 2.085 & 142.61 \\
\hline Maximum power takeoff at $1,900 \mathrm{rpm}$ & 2.085 & 142.45 \\
\hline Maximum engine power at $2,097 \mathrm{rpm}$ & 1.985 & 124.09 \\
\hline \multicolumn{3}{|l|}{9400 Tractor: $425 \mathrm{hp}$} \\
\hline Power takeoff at $2,100 \mathrm{rpm}$ & 2.210 & 141.21 \\
\hline Standard power takeoff at $1,900 \mathrm{rpm}$ & 2.315 & 148.21 \\
\hline Maximum power takeoff at $1,900 \mathrm{rpm}$ & 2.315 & 148.21 \\
\hline Maximum engine power at $2,101 \mathrm{rpm}$ & 2.605 & 132.34 \\
\hline
\end{tabular}

${ }^{a}$ From http://products.deere.com/webapp/commerce/command/CategoryDisplay?path= FR\&cgnbr=Tractors (accessed 8/29/02). For diesel fuels, $1 \mathrm{mmBtu}$ is equal to 7.78 gal of CD.

While fuel consumption rate increases monotonically for these tractors, specific power output per mmBtu of fuel used at rated speed (rpm) is remarkably uniform, as shown in Table 7.

EPA's 1991 off-road emissions study (EPA 1991) assigned emission factors in g/hp-h and $\mathrm{lb} / 1,000 \mathrm{gal}$ of diesel fuel to agricultural tractor operation. Corresponding pollutant values are listed in Table 8. 
Table 8. Emissions from Agricultural Tractors $^{\mathrm{a}}$

\begin{tabular}{|c|c|c|}
\hline \multirow[t]{2}{*}{ Pollutant } & \multicolumn{2}{|c|}{ Emissions } \\
\hline & g/hp-hr & $\begin{array}{c}\text { lb/1,000 gal } \\
\text { of diesel }\end{array}$ \\
\hline $\mathrm{HC}$ & 1.59 & 63.55 \\
\hline $\mathrm{CO}$ & 4.47 & 174.9 \\
\hline $\mathrm{NO}_{\mathrm{x}}$ & 11.19 & 438.6 \\
\hline $\mathrm{PM}_{10}$ & 1.17 & 45.7 \\
\hline $\mathrm{SO}_{\mathrm{x}}$ & 0.80 & 31.2 \\
\hline \multicolumn{3}{|c|}{$\begin{array}{l}\text { a Based on EPA (1991); the values listed } \\
\text { incorporate a specific power factor of about } 138 \\
\text { hp-hr/mmBtu. }\end{array}$} \\
\hline \multicolumn{3}{|c|}{$\begin{array}{c}\text { Table 9. Emissions Factors with the Estimate } \\
\text { Fuel Consumption }\end{array}$} \\
\hline \multirow[t]{2}{*}{ Pollutant } & \multicolumn{2}{|c|}{ Emissions } \\
\hline & $\mathrm{g} / \mathrm{hr}$ & g/mmBtu \\
\hline $\mathrm{HC}$ & 580 & 265 \\
\hline $\mathrm{CO}$ & 1,630 & 745 \\
\hline $\mathrm{NO}_{\mathrm{x}}$ & 4,085 & 1,865 \\
\hline $\mathrm{PM}_{10}$ & 430 & 195 \\
\hline $\mathrm{SO}_{\mathrm{x}}$ & 290 & 130 \\
\hline
\end{tabular}

To perform $\mathrm{CO}_{2}$ calculations, it is necessary to apply the fuel consumption (FC) relationship (expressed in gal), as calculated across the spectrum of Deere tractors, i.e., $\mathrm{FC} / \mathrm{hr}=0.0413 \mathrm{hp}+2.09\left(r^{2}=0.96\right)$. For the 365 -hp tractor, this translates to $17.1 \mathrm{gal}$ of diesel fuel (or $2.19 \mathrm{mmBtu}$ ) per hour. The tractor power range covering $70 \mathrm{hp}$ to either side of the $365 \mathrm{hp}$ yields a fuel consumption range between 14 and $20 \mathrm{gal} / \mathrm{hr}$. Applying EPA factors to convert from mmBtu to hours gives the approximate (rounded to the nearest 5) midpoint emission factors listed in Table 9 (g/hr, g/mmBtu).

EPA estimates that agricultural tractors operate about $411 \mathrm{hrs} / \mathrm{yr}$ (90\% of that occurs from March to October) - meaning our average tractor consumes about 7,030 gal (905 mmBtu) of diesel per year and, according to the Nonroad Engine and Vehicle Emission Study (EPA 1991), emits $1,690 \mathrm{~kg} \mathrm{NO}$, $240 \mathrm{~kg}$ hydrocarbons (HC), $675 \mathrm{~kg} \mathrm{CO}, 175 \mathrm{~kg} \mathrm{PM}_{10}$, and $120 \mathrm{~kg} \mathrm{SO}$ х per year (about 95\% during the 6-8 month growing season).

EPA's NONROAD model (EPA 2002a) is still officially in draft form (not approved for state implementation plan submissions), but it provides significantly updated rates, based on emission control technology level, for diesel agricultural tractors relative to the 1991 values. In this case, each emission control tier (based on current and future standards) generally corresponds to a control technology set. Tractors are already under Tier 1 control (see Table 10), and Tier 2 begins next year. The current tractor fleet age distribution is approximately $60 \%$ base, $30 \%$ Tier 0 , and $10 \%$ Tier 1 . In the long term, the fleet will be covered $100 \%$ by Tier 2 and Tier 3 . Under Tier 3, tractors cannot use 3,000-ppm-S diesel fuel. We assumed 350-ppm-S diesel for Tier 2 and Tier 3 nonroad vehicles. 
Table 10. Criteria Pollutant Emissions from Nonroad Tractors in $\mathrm{g} / \mathrm{hp}-\mathrm{hr}$

\begin{tabular}{|l|c|c|c|c|c|}
\hline Pollutant & Base Rate & Tier 0 & Tier 1 & Tier 2 & $\begin{array}{c}\text { Tier 3 } \\
\text { (after 2007) }\end{array}$ \\
\hline $\mathrm{THC}$ & 1.42 & 0.60 & 0.319 & 0.32 & 0.16 \\
\hline $\mathrm{CO}$ & 1.88 & 1.13 & 0.52 & 0.52 & 0.52 \\
\hline $\mathrm{NO}_{\mathrm{x}}$ & 11.10 & 8.38 & 5.452 & 3.76 & 2.35 \\
\hline $\mathrm{PM}_{10}$ & 0.82 & 0.25 & 0.156 & 0.10 & 0.10 \\
\hline
\end{tabular}

Based on the relatively constant conversion factor $18 \mathrm{hp}$-hr/gal of diesel fuels, we converted these rates into $\mathrm{g} / \mathrm{mmBtu}$ (Table 11 ).

Table 11. Criteria Pollutant Emissions from Nonroad Tractors in $\mathrm{g} / \mathrm{mmBtu}$

\begin{tabular}{|l|c|c|c|c|c|}
\hline Pollutant & Base Rate & Tier 0 & Tier 1 & Tier 2 & $\begin{array}{c}\text { Tier 3 } \\
\text { (after 2007) }\end{array}$ \\
\hline $\mathrm{THC}$ & 200 & 84 & 45 & 45 & 22 \\
\hline $\mathrm{CO}$ & 260 & 160 & 72 & 72 & 72 \\
\hline $\mathrm{NO}_{\mathrm{x}}$ & 1,550 & 1,170 & 760 & 525 & 330 \\
\hline $\mathrm{PM}_{10}$ & 115 & 35 & 22 & 14 & 14 \\
\hline
\end{tabular}

We have assumed that tractors fueled by ED10 in a future of widespread use will comply with Tier 2 standards, with a very small proportion (1.5\%) that are Tier 3 compliant. This level of stringency will, on average, not require (but can accept) the use of low-sulfur (15-ppm) diesel.

In heavy-duty truck tests conducted by Southwest Research Institute (SwRI) for Archer Daniels Midland (ADM) (Marek and Evanoff 2001), two 1999 model year Mack E-7 units were tested (see Marek and Evanoff 2001). The ED10 experienced a net 7\% loss in fuel economy (by fuel volume) relative to diesel fuel, while ED15 experienced a 10\% loss. PM emissions were down in both cases by at least $20 \%$, and these are recent-technology engines. $\mathrm{NO}_{\mathrm{x}}$ emissions were about the same.

ED10 emissions testing was also performed by the Colorado School of Mines for AAE/OctelStarreon on a 1991 DDC Series 60 (Peeples and MacMillan 2001). The researchers reported a small $(2 \%$ to $5 \%)$ net $\mathrm{NO}_{\mathrm{x}}$ reduction - which is lost in the noise because some rpm/load combinations actually increased $\mathrm{NO}_{\mathrm{x}}$ (a finding duplicated during Volkswagen engine testing by Automotive Testing Laboratory and Argonne National Laboratory [Cole et al. 2000]), as well as a $20 \%$ to $25 \%$ CO reduction and a $25 \%$ PM reduction (when looking at the actual representative segments of the engine map on which the unit was tested).

Based on the above considerations, for ED10 in agricultural tractor applications, we applied emission rates that correspond to the assumed changes relative to conventional diesel, as listed in Table 12. 
Table 12. Fuel Consumption (mmBtu/hr) and Emissions $(\mathrm{g} / \mathrm{mmBtu})$ of Agricultural Tractors Fueled by Conventional Diesel, ED10, and ED15

\begin{tabular}{|c|c|c|c|c|}
\hline & $\begin{array}{c}\text { Conventional } \\
\text { Diesel }\end{array}$ & $\begin{array}{c}\text { Relative Change } \\
\text { of ED10, ED15 (\%) }\end{array}$ & ED10 & ED15 \\
\hline Fuel Use (mmBtu/hr) & 2.19 & $0.5,4$ & 2.2 & 2.27 \\
\hline Emissions (g/mmBtu) & \multicolumn{5}{|l}{} \\
\hline $\mathrm{VOC}$ & 45 & $5,7.5$ & 46.5 & 47.6 \\
\hline $\mathrm{CO}$ & 72 & $-10,-15$ & 64.8 & 61.2 \\
\hline $\mathrm{NO}_{\mathrm{x}}$ & 525 & 0,2 & 525 & 535.5 \\
\hline $\mathrm{PM}_{10}$ & 14 & $-20,-25$ & 11.2 & 10.5 \\
\hline $\mathrm{N}_{2} \mathrm{O}$ & 0.92 & $5,7.5$ & 0.96 & 0.99 \\
\hline $\mathrm{CH}_{4}$ & 0.63 & $5,7.5$ & 0.66 & 0.68 \\
\hline
\end{tabular}

\section{Transit Buses on E-Diesel Blends}

There is very little information about consistent, controlled tests of buses using E-diesel. One source is the testing conducted at Automotive Testing Laboratory and overseen by Argonne on the Volkswagen turbocharged direct-injection diesel light-duty engine (Cole et al. 2000). Also, the Chicago Transit Authority, in conjunction with SwRI, has conducted limited testing on buses fueled by ED15 (Marek and Evanoff 2001). These experiments showed no net fuel efficiency loss for an E-diesel blend relative to premium diesel (which may have a lower heating value than diesel \#2).

Based on the limited results from Cole et al. (2000), we used the following modifications to standard diesel transit bus emission rates in MOBILE6 (Table 13), the latest version of EPA's MOBILE model for estimating vehicle emission factors (EPA 2002b). 
Table 13. Baseline Bus Emission Rates and ED-Fueled Bus Emission Changes

\begin{tabular}{|c|c|c|c|c|c|}
\hline & $\begin{array}{l}\text { Near-term } \\
\text { (300-ppm-S } \\
\text { diesel) buses }\end{array}$ & $\begin{array}{l}\text { Long-term }^{a} \\
\text { (15-ppm-S } \\
\text { diesel) buses }\end{array}$ & $\begin{array}{c}\text { Changes by } \\
\text { buses with } \\
\text { ED10, ED15 } \\
(\%)\end{array}$ & $\begin{array}{c}\text { Buses } \\
\text { with } \\
\text { ED10 }\end{array}$ & $\begin{array}{c}\text { Buses } \\
\text { with } \\
\text { ED15 }\end{array}$ \\
\hline Btu content: Btu/gal & 128,500 & 128,500 & NA & 123,120 & 120,430 \\
\hline $\begin{array}{l}\text { Fuel economy } \\
\text { (mi/volumetric gal) }\end{array}$ & 3.73 & 3.73 & $-6,-10$ & 3.51 & 3.36 \\
\hline $\begin{array}{l}\text { Fuel economy } \\
\text { (mi/gasoline-equiv. gal) }\end{array}$ & 3.35 & 3.35 & $-2,-4$ & 3.28 & 3.22 \\
\hline \multicolumn{6}{|l|}{ Emissions (g/mi) } \\
\hline VOC & 0.57 & 0.488 & $5,7.5$ & 0.513 & 0.525 \\
\hline $\mathrm{CO}$ & 7.8 & 4.75 & $-10,-15$ & 4.28 & 4.04 \\
\hline $\mathrm{NO}_{\mathrm{x}}$ & 23 & 13.24 & 0,2 & 13.24 & 13.5 \\
\hline $\mathrm{PM}_{10}$ & 0.34 & 0.217 & $-20,-25$ & 0.174 & 0.163 \\
\hline $\mathrm{N}_{2} \mathrm{O}$ & & 0.01 & 0 & 0.01 & 0.01 \\
\hline $\mathrm{CH}_{4}$ & & 0.007 & 0 & 0.007 & 0.007 \\
\hline
\end{tabular}

${ }^{a}$ Long-term baseline bus emissions are estimated by using EPA's MOBILE6 except for $\mathrm{N}_{2} \mathrm{O}$ and $\mathrm{CH}_{4}$, which are GREET-based estimates.

Our decision regarding appropriate modifications to fuel consumption rates was not so straightforward. The limited testing on ED15 by the Chicago Transit Authority, in conjunction with SwRI, showed no statistically identifiable net fuel efficiency difference for an E-diesel blend relative to premium diesel. However, during the experiment E-diesel-fueled buses and the control neat diesel-fueled buses did not run the same routes under the same conditions because the test's purpose was simply to establish the viability of using ED15 in regular mass transit service. In fact, the 15 ED blend-fueled buses collectively accumulated 75,000 fewer service miles over the test period than their 15 control counterparts. The SwRI tests with the two Mack trucks were somewhat better controlled statistically and enabled a more legitimate "apples-toapples" comparison of performance, even though the driving schedules and patterns were arguably not representative of transit buses. (Of course, this raises the question of whether transit bus operations in Chicago are representative of those of transit fleets in other cities that may one day use E-diesel.) We decided to adopt the SwRI heavy-duty results for ED15 as a defensible (if conservative) indicator for heavy-duty operations on ED15 generally. As shown in Table 13, we assigned a $10 \%$ volumetric fuel economy penalty to ED15/low-sulfur diesel blends relative to straight low-sulfur diesel.

We note that test results for tractors and buses using diesel and E-diesel are very limited. In fact, there were no controlled tests that assured that diesel and E-diesel would be tested in typical operating conditions for tractors or buses. 


\section{Results}

Figures 3 through 5 (covering model outputs) and 6 through 8 (covering case-to-case comparisons) present some key results of the GREET analysis. In each figure, the bars represent mean values, and the lines superimposed on the bars represent uncertainty ranges. As shown in Figures $3 \mathrm{a}$ and $3 \mathrm{~b}$, the spread in energy consumption rates in Btu/hr (tractor) or Btu/mi (bus) is largely a function of the range of representative hourly or per-mile fuel consumption rate (midpoint value plus or minus 18\% for the tractor and 10\% for the urban bus).

Not surprisingly, the fossil and petroleum shares decline across the fuels as an approximate function of percentage of ethanol, but not as dramatically as would be the case if ethanol mills and farming operations were powered predominantly by non-fossil fuels. In the case of global warming precursors (Figures $4 \mathrm{a}$ and $4 \mathrm{~b}$ ), total (GWP-weighted) fuel-to-fuel relationships in GHG emission rates are comparable for all cases, but the $\mathrm{GHG} / \mathrm{CO}_{2}$ ratio is slightly higher for the

E-diesel fuels because of higher $\mathrm{N}_{2} \mathrm{O}$ and methane concentrations in the WTP component for ethanol. Because fine-PM emissions are a concern in urban areas, we note in Figures $5 \mathrm{a}$ and $5 \mathrm{~b}$ that the urban component of such emissions, while negligible for tractors, displays a very slight advantage for buses fueled by E-diesel over petroleum diesel counterparts, but the magnitude is probably not sufficient to drive fuel-oriented urban emission control policy decisions. Also note that total (i.e., urban and rural) fine-PM emissions are greater with the E-fuels because of their greater reliance on coal (upstream) as power plant fuel and process fuel.

Although use of E-diesel can achieve reductions in petroleum use (Figure 6a), the energy- and GHG-related net changes relative to use of conventional diesel (tractor) and low-sulfur diesel (bus) respectively, as shown in Figures $6 \mathrm{a}$ and $6 \mathrm{~b}$, do not establish a conclusive case for the superiority of E-diesel fuels. Within the range of our assumptions, as modeled within the 10\% and $90 \%$ extreme values, it is possible that both ED10 and ED15 could produce greater overall emissions and consume more total energy and fossil fuels per unit of activity than neat diesel. Our analysis also shows that E-diesel fuels are likely to require more total energy input per unit of output heating value than either conventional or low-sulfur diesel. On the other hand, despite a relatively weak overall performance on total criteria pollutant emissions (Figure 7), buses fueled by E-diesel, do show a net reduction in important pollutants $\left(\mathrm{PM}_{10}\right.$ and $\left.\mathrm{CO}\right)$ in urban areas (Figure 8). They are essentially neutral on VOCs as well as on $\mathrm{NO}_{\mathrm{x}}$ and $\mathrm{SO}_{\mathrm{x}}$ (VOC emission rates per unit of travel by diesels are so small to begin with that percentage changes less than $100 \%$ or so are inconsequential). Thus, the combined net benefit of petroleum displacement and reduction in urban fine particulate loading is possibly an attractive environmental and energy policy-oriented feature of E-diesel fuels. 


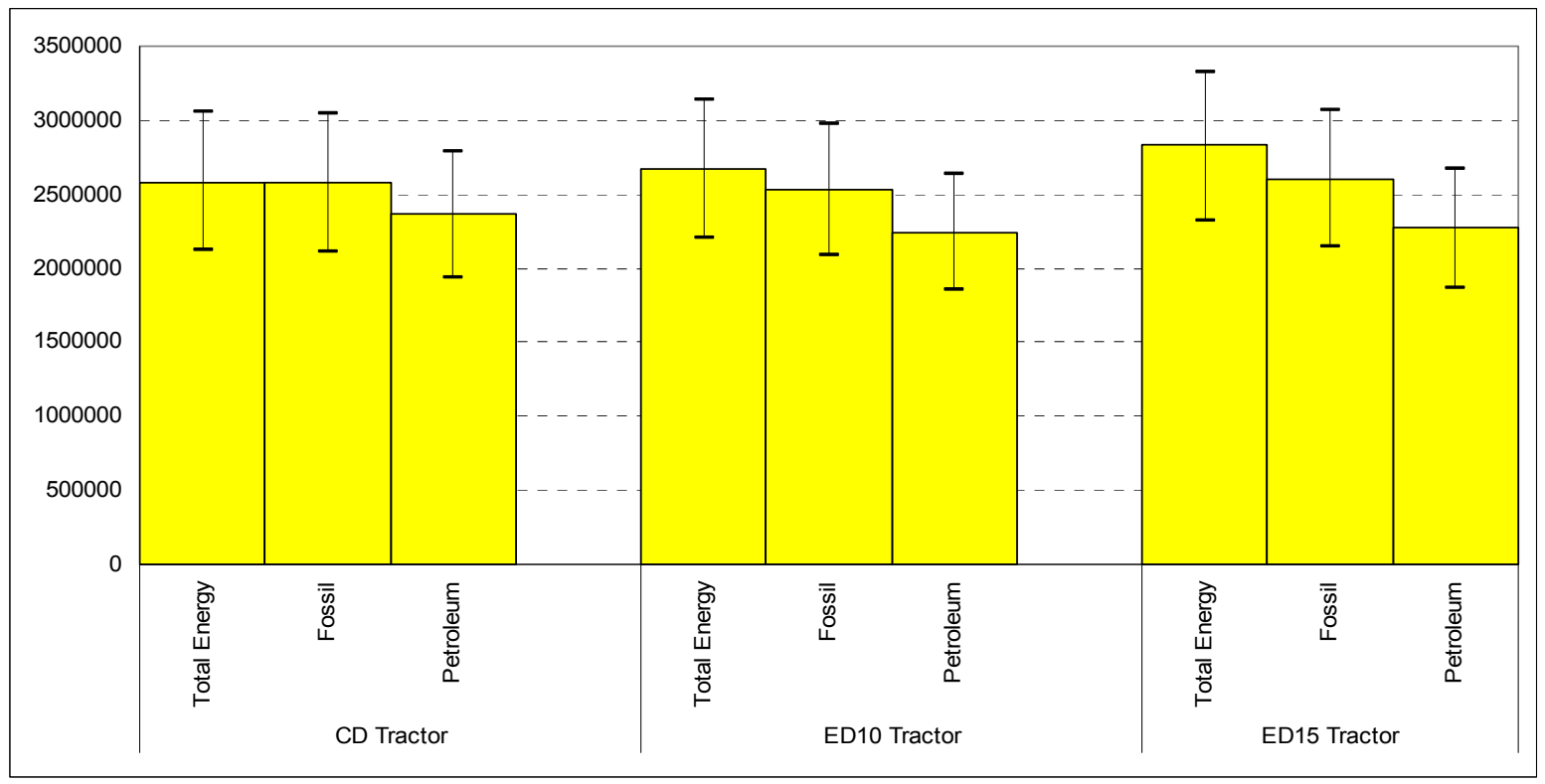

(a) Farming Tractors (Btu/hr)

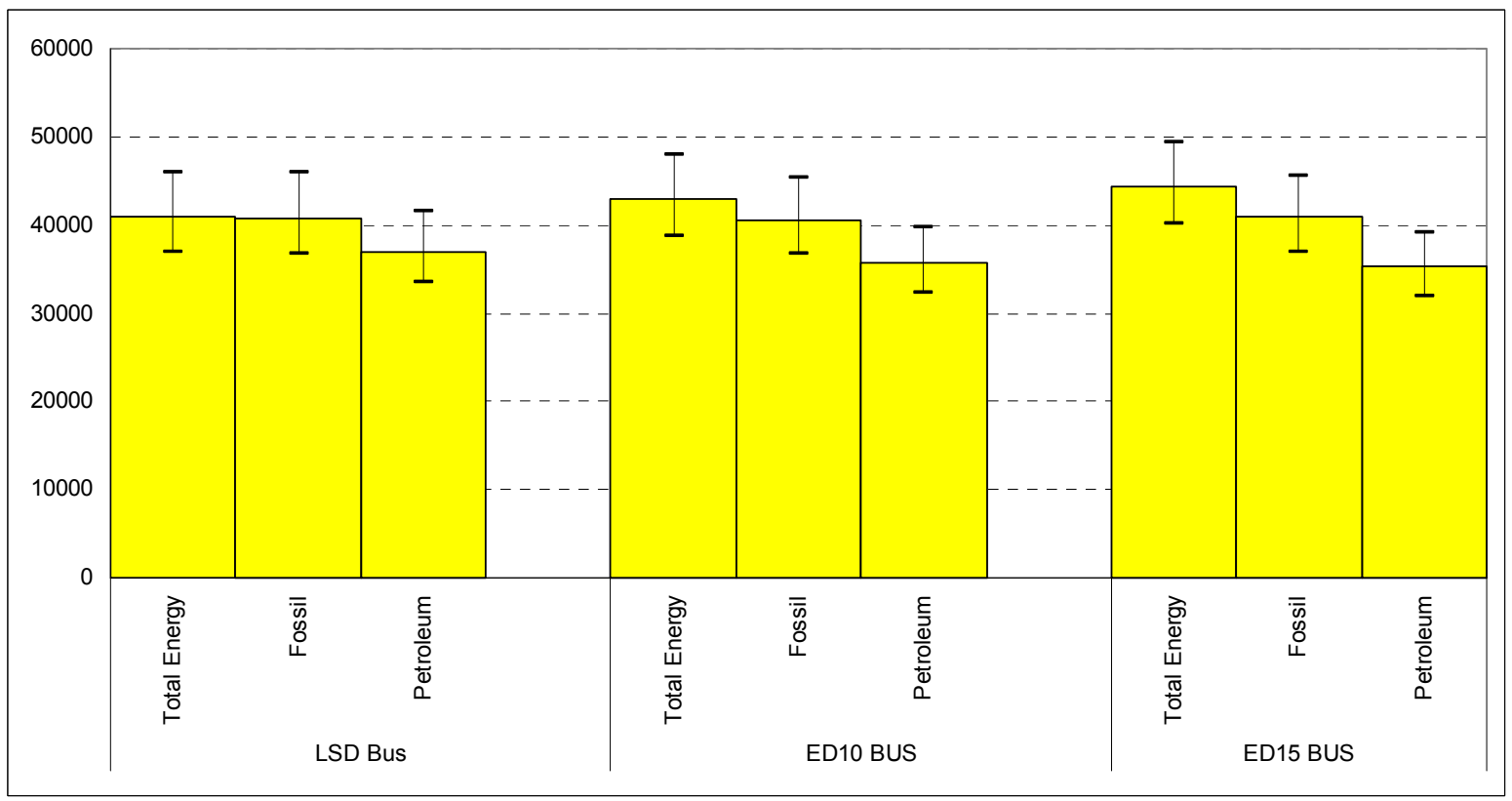

(b) Urban Buses (Btu/mi)

Figure 3. Well-to-Wheels Energy Use of Farming Tractors and Urban Bases 


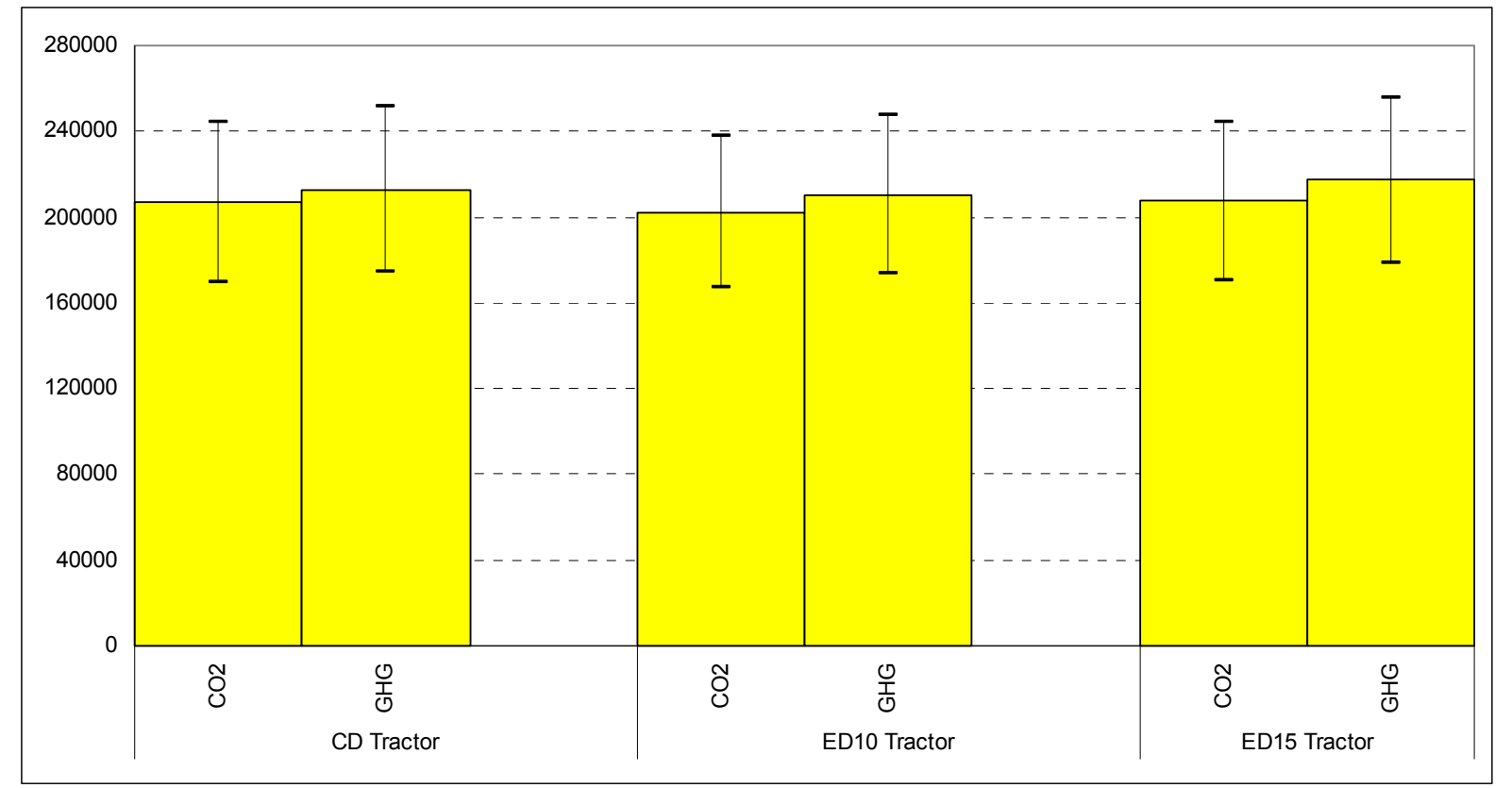

(a) Farming Tractors $(\mathrm{g} / \mathrm{hh})$

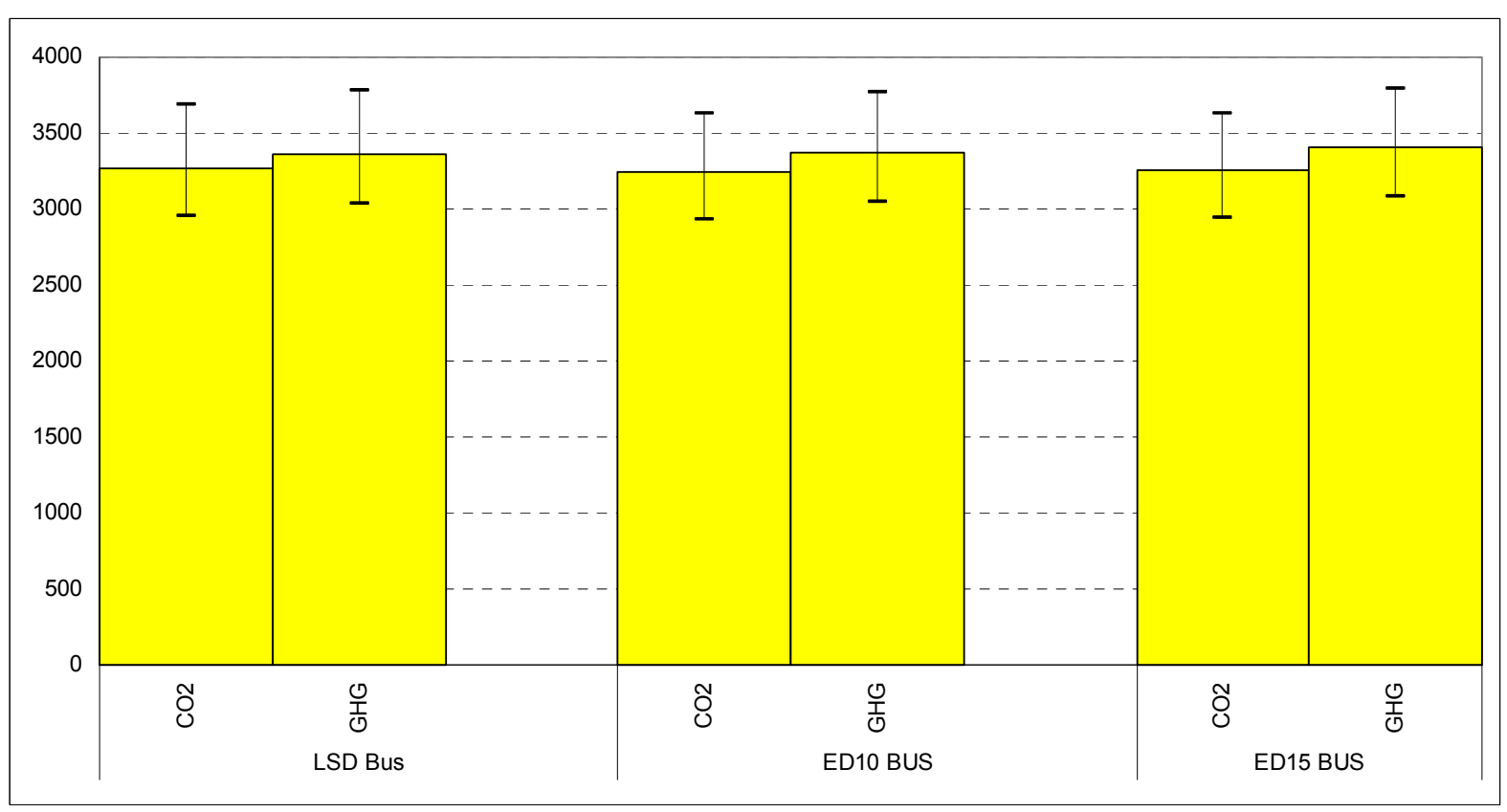

(b) Urban Buses ( $\mathrm{g} / \mathrm{mi})$

Figure 4. Well-to-Wheels $\mathrm{CO}_{2}$-Equivalent GHG Emissions of Farming Tractors and Urban Buses 


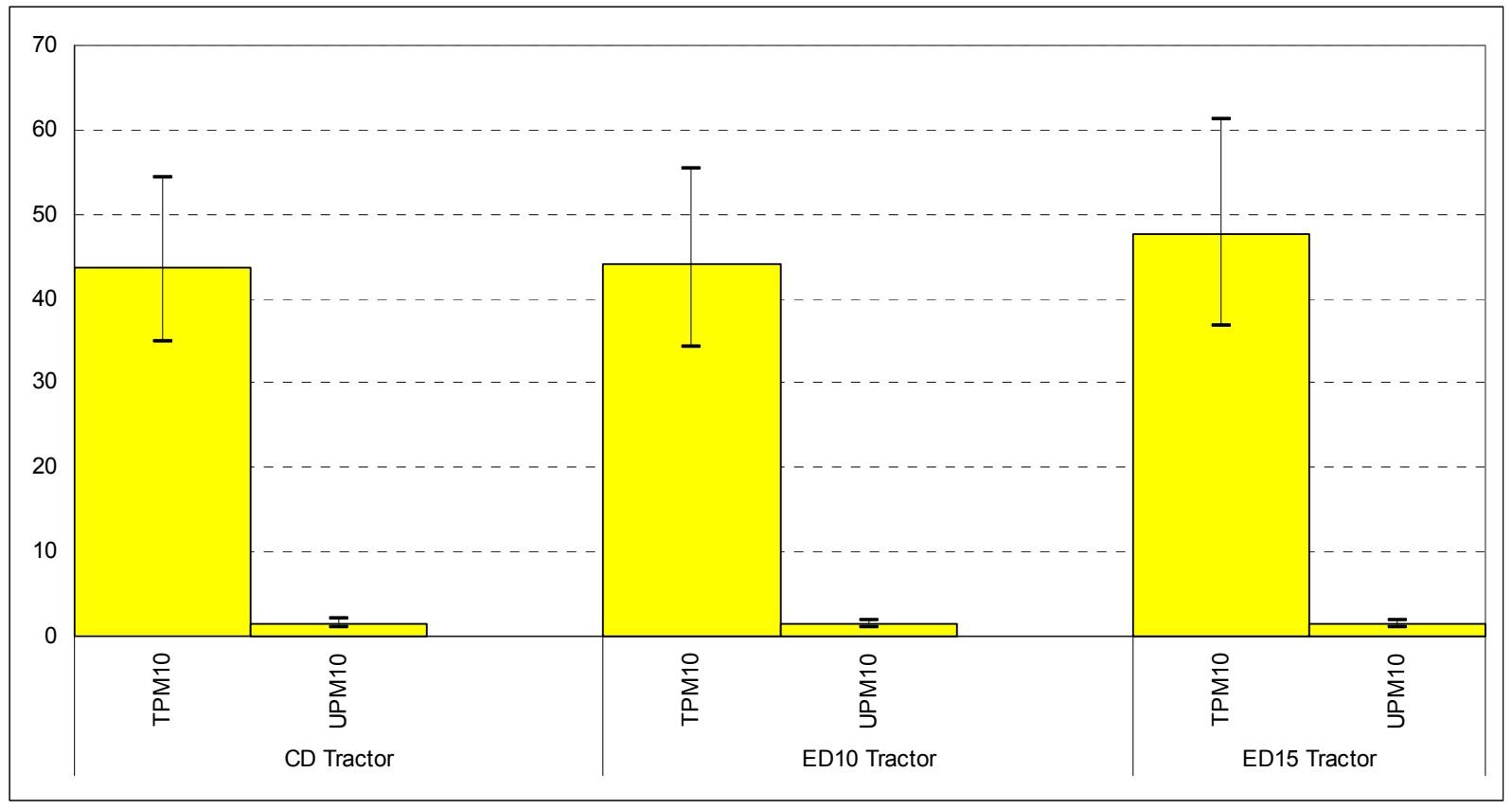

(a) Farming Tractors $(\mathrm{g} / \mathrm{hr})$

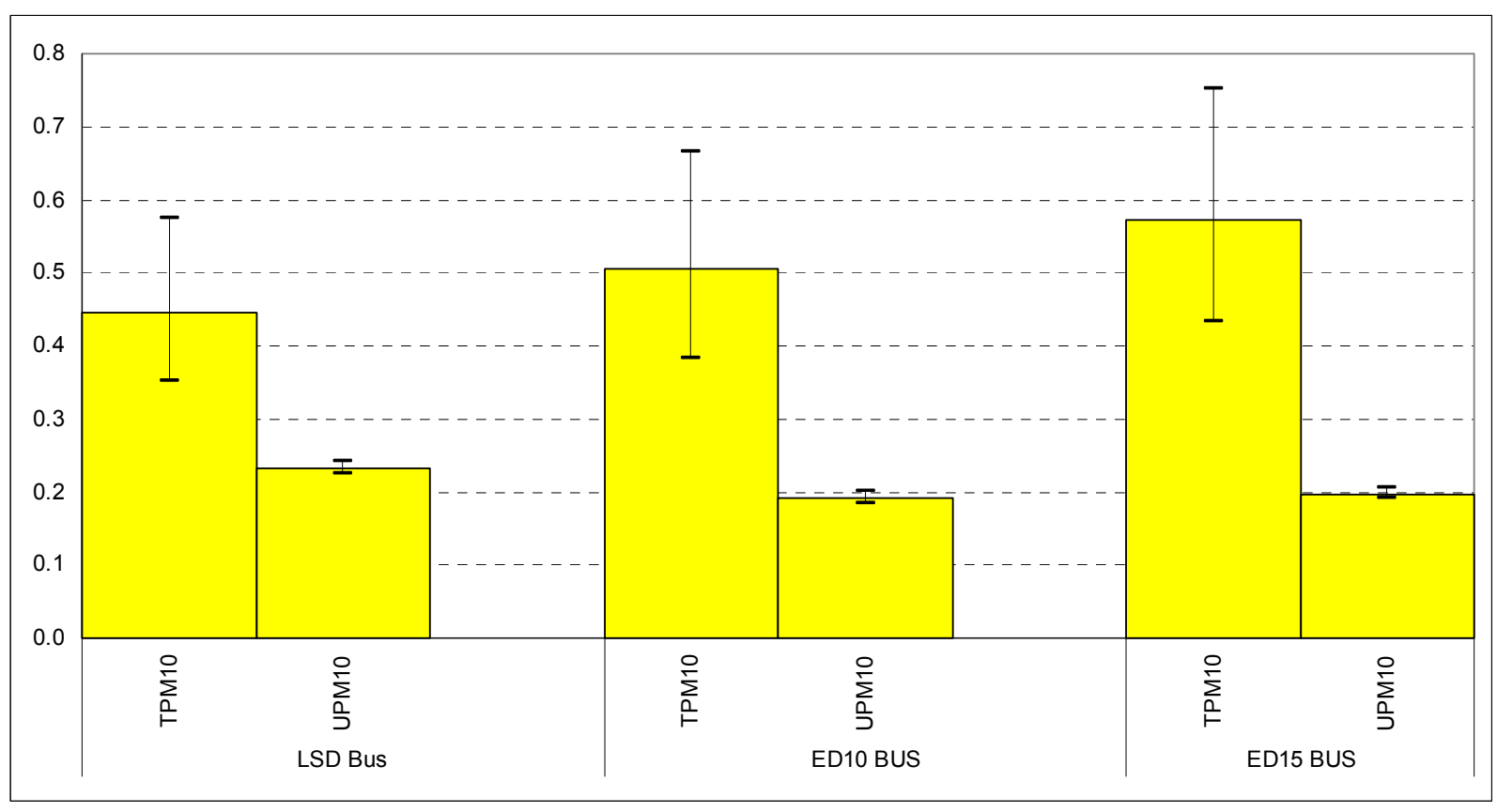

(b) Urban Buses (g/mi)

Figure 5. Well-to-Wheels $\mathrm{PM}_{10}$ Emissions of Farming Tractors and Urban Buses 


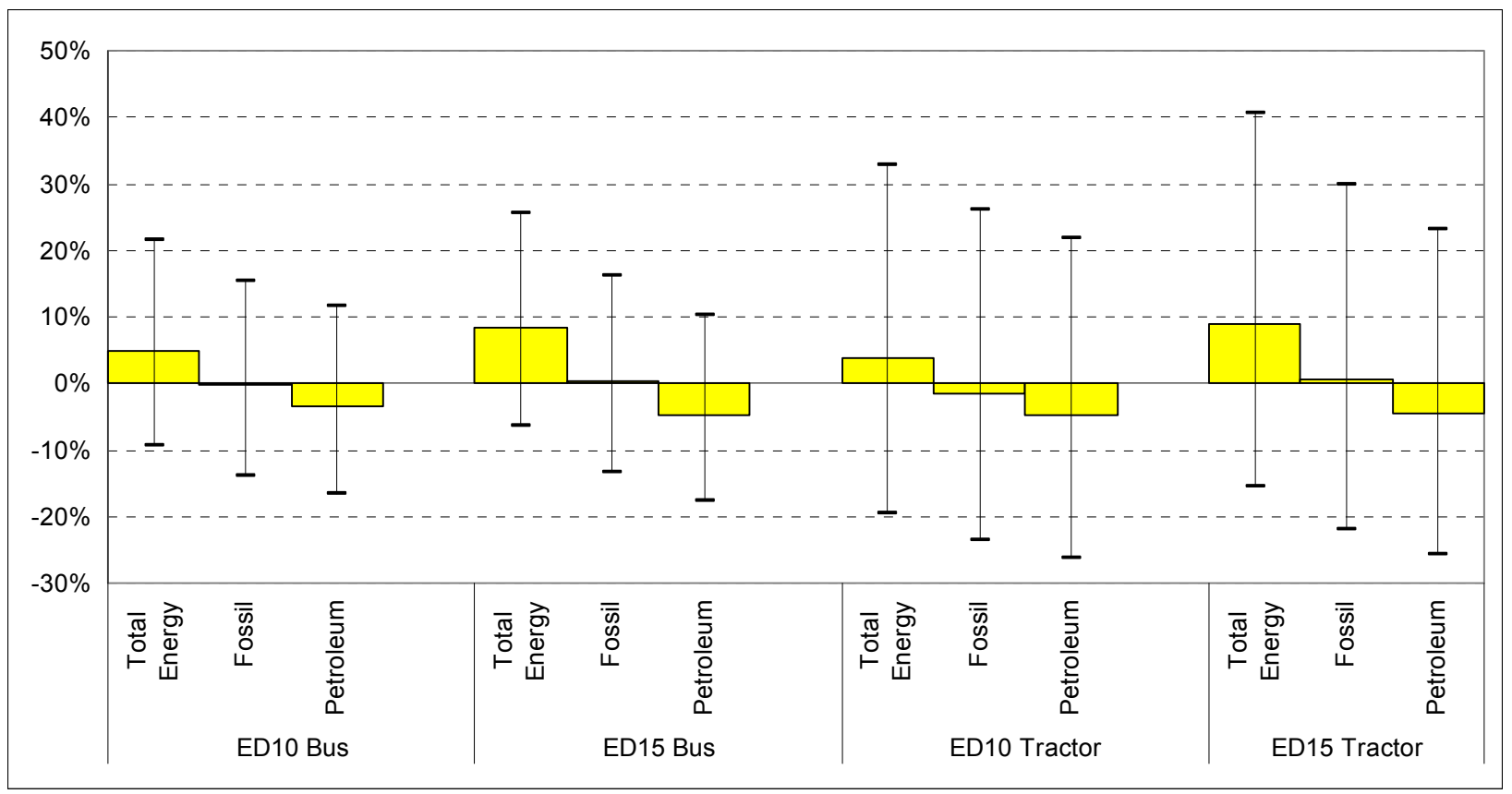

(a) Well-to-Wheels Energy Use Changes

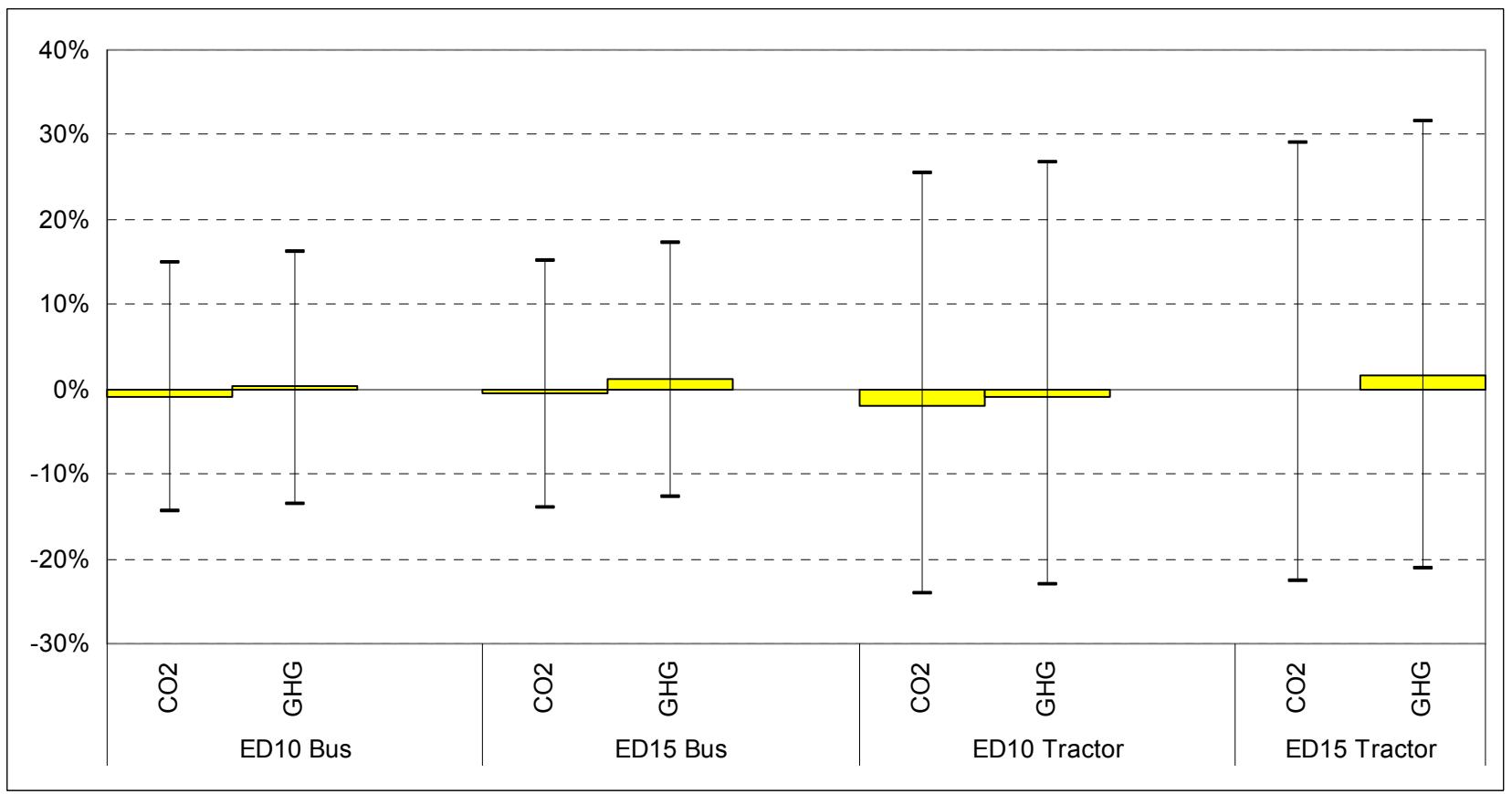

(b) Well-to-Wheels GHG Emission Changes

Figure 6. Well-to-Wheels Energy Use and GHG Emission Changes of Farming Tractors and Urban Buses (results are relative to those of tractors fueled by CD and buses fueled by LSD) 


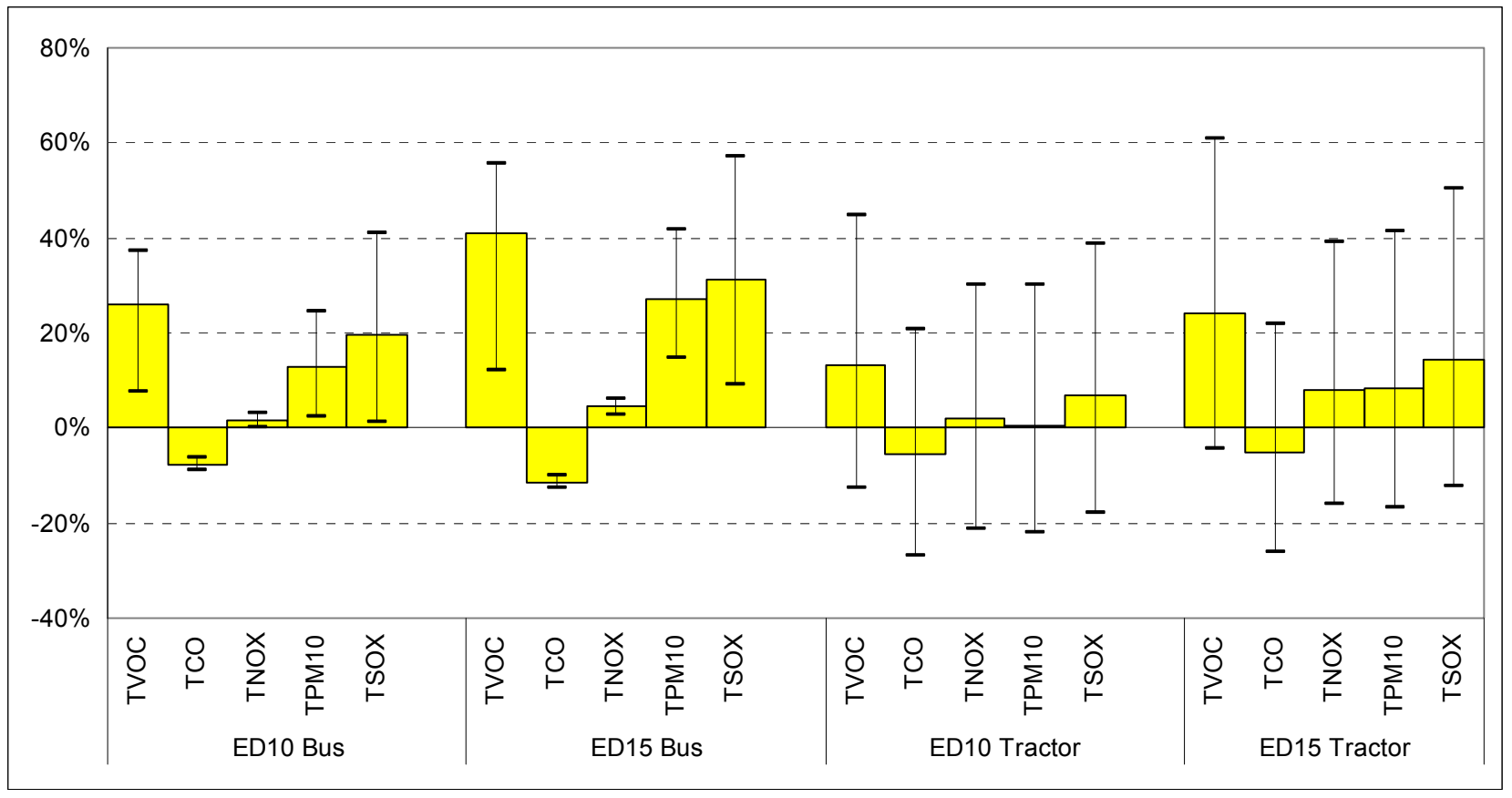

Figure 7. Well-to-Wheels Changes in Total Criteria Pollutant Emissions of Farming Tractors and Urban Buses (results are relative to those of tractors fueled by CD and buses fueled by LSD)

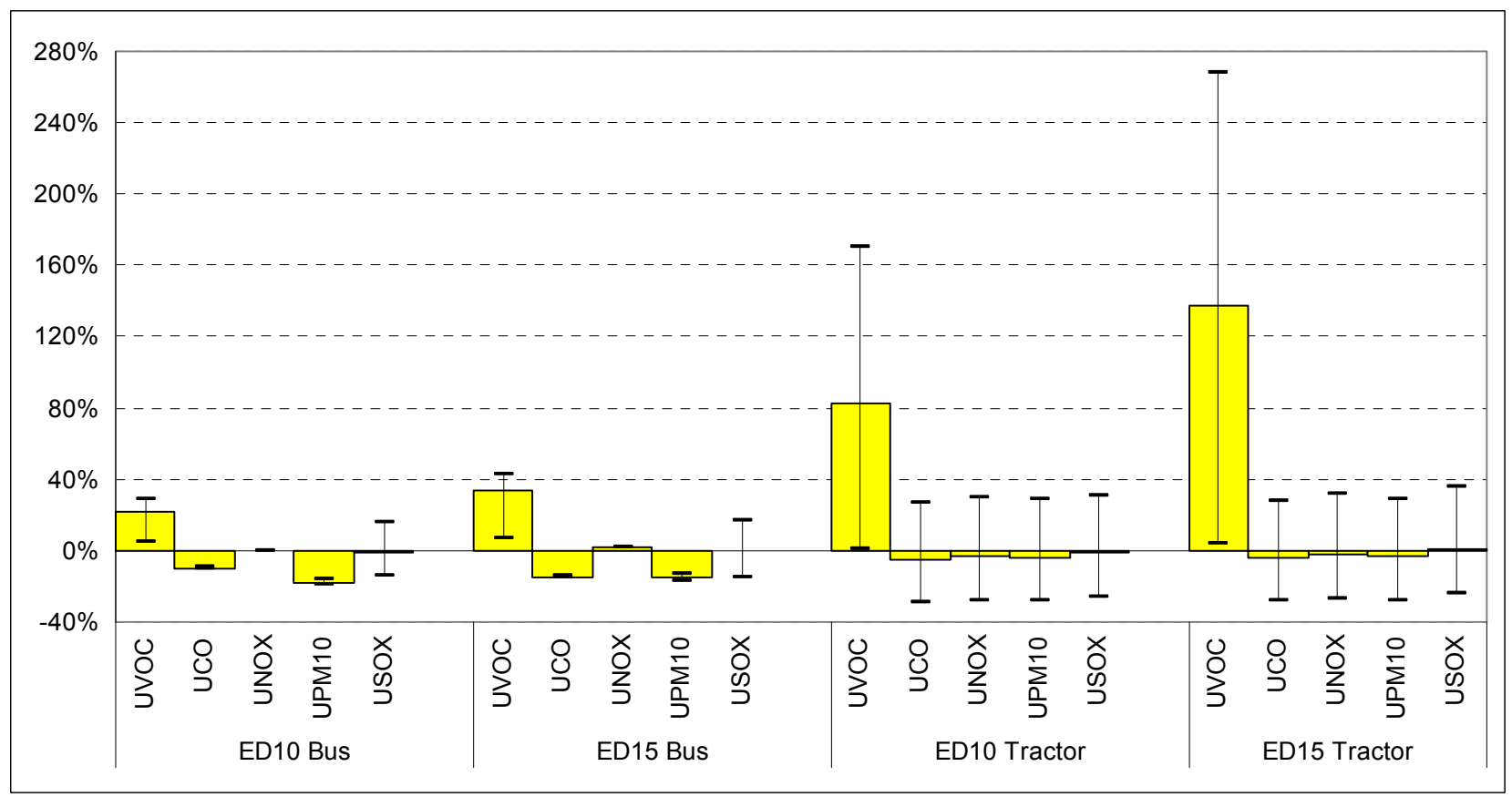

Figure 8. Well-to-Wheels Changes in Urban Criteria Pollutant Emissions of Farming Tractors and Urban Buses (results are relative to those of buses fueled by LSD) 


\section{Conclusions}

Using Argonne's GREET model, we conducted a WTW analysis of E-diesel blends vs. petroleum diesel for applications in farming tractors and urban buses. Our results show that use of ED10 or ED15 might result in increases in total energy use, but in reductions in fossil energy use and significant reductions in petroleum use relative to use of conventional or low-sulfur diesel fuel. In our total energy use calculations, energy consumption was taken into account for both ethanol and petroleum diesel, but in the calculations of fossil fuel and petroleum use, only energy in petroleum diesel was taken into account because the energy in ethanol is $100 \%$ renewable. The magnitude of the reduction in fossil fuel use by E-diesel blends is limited by the use of coal, natural gas, liquefied petroleum gas, diesel, and electricity during corn farming, ethanol production, and ethanol transportation.

Use of E-diesel blends relative to use of petroleum diesel results in few changes in GHG emissions - in contrast to GHG emission results showing moderate benefits for ethanolgasoline blends vs. gasoline. This disparity is primarily caused by two factors. First, the WTP GHG emissions of diesel fuels are smaller than those of petroleum gasoline because WTP energy efficiencies for diesel fuels are higher than those for gasoline. Second, on an energy basis, while ethanol-gasoline blend use in ethanol-capable vehicles results in little fuel economy change relative to neat gasoline (despite ethanol-gasoline blends having somewhat lower volumetric fuel economy), E-diesel blends offer heating value-based fuel economy that is lower than that of petroleum diesel.

Our analysis shows that the most noteworthy benefits of E-diesel use lie with petroleum reductions and reductions in urban $\mathrm{PM}_{10}$ and $\mathrm{CO}$ emissions by urban bus operations. We acknowledge that the overall effect of farming tractors and urban buses on the nation's petroleum use is tiny, and that urban $\mathrm{CO}$ emissions are increasingly becoming a non-issue for major U.S. cities. However, specifically with respect to pollution abatement, E-diesel could be a non-trivial asset of fuel portfolios for urban buses needing to reduce their $\mathrm{PM}_{10}$ emissions.

\section{Acknowledgments}

This study was funded by the Illinois Department of Commerce and Community Affairs. We are grateful for input from DCCA's project manager, David Loos. We thank Mary Fitzpatrick of Argonne's Information Publishing Division for editing this report. The authors are solely responsible for the results presented in this report. 


\section{References}

Association of American Plant Food Control Officials (AAPFCO) and The Fertilizer Institute, 2001, Commercial Fertilizers 2000, Washington, D.C., prepared by D.L. Peiry and B.J. Kirby, University of Kentucky, Lexington, KY, May.

Brown, H.L., B.B. Hamel, B.A. Hedman, M. Koluch, B.C. Cajanana, and P. Troy, 1996, Energy Analysis of 108 Industrial Processes, The Fairmont Press, Inc., Lilburn, GA.

Cole, R.L., R.B. Poola, R. Sekar, J.E. Schaus, and P. McPartlin, 2000, Effect of Ethanol Fuel Additive on Diesel Emissions, ANL/ESD/TM-162, Center for Transportation Research, Argonne National Laboratory, Argonne, IL, Aug.

European Fertilizer Manufacturers' Association (EFMA), 1995, Best Available Techniques for Pollution Prevention and Control in the European Fertilizer Industry, Booklet No. 4: Production of Phosphoric Acid, Brussels, Belgium.

European Fertilizer Manufacturers' Association (EFMA), 2000a, Best Available Techniques for Pollution Prevention and Control in the European Fertilizer Industry, Booklet No. 1: Production of Ammonia, Brussels, Belgium.

European Fertilizer Manufacturers' Association (EFMA), 2000b, Best Available Techniques for Pollution Prevention and Control in the European Fertilizer Industry, Booklet No. 5: Production of Urea and Urea Ammonium Nitrate, Brussels, Belgium.

European Fertilizer Manufacturers' Association (EFMA), 2000c, Best Available Techniques for Pollution Prevention and Control in the European Fertilizer Industry, Booklet No. 2: Production of Nitric Acid, Brussels, Belgium.

European Fertilizer Manufacturers' Association (EFMA), 2000d, Best Available Techniques for Pollution Prevention and Control in the European Fertilizer Industry, Booklet No. 6: Production of Ammonium Nitrate and Calcium Ammonium Nitrate, Brussels, Belgium.

Flessa, H., and P. Dorsch, 1995, "Seasonal Variation of $\mathrm{N}_{2} \mathrm{O}$ and $\mathrm{CH}_{4}$ Fluxes in Differently Managed Arable Soils in Southern Germany," J. Geoph. Res., 100:D11, 23.115-23.124.

Food and Agriculture Organization of the United Nations, 1999, Current Trends in the Production, Trade and Consumption of Chemical Fertilizers, Statistical Analysis Service, Statistics Division, Rome, Italy, Sept.

General Motors Corporation, Argonne National Laboratory, BP, ExxonMobil, and Shell, 2001a, Well-to-Wheel Energy Use and Greenhouse Gas Emissions of Advanced Fuel/Vehicle Systems: A North American Analysis, Volume 1, Executive Summary Report, ANL/ES/RP-104528, June.

General Motors Corporation, Argonne National Laboratory, BP, ExxonMobil, and Shell, 2001b, Well-to-Wheel Energy Use and Greenhouse Gas Emissions of Advanced Fuel/Vehicle Systems: A 
North American Analysis, Volume 2, Report, ANL/ES/RP-104528, June.

General Motors Corporation, Argonne National Laboratory, BP, ExxonMobil, and Shell, 2001c, Well-to-Wheel Energy Use and Greenhouse Gas Emissions of Advanced Fuel/Vehicle Systems: A North American Analysis, Volume 3, Well-to-Tank Energy Use and Greenhouse Gas Emissions of Transportation Fuels, ANL/ES/RP-104528, June.

Graboski, M.S., 2002, Fossil Energy Use in the Manufacture of Corn Ethanol, prepared by the Colorado School of Mines for the National Corn Growers Association, Washington, D.C., August.

Hansen, A.C., R.H. Hornbaker, Q. Zhang, and P.W.L. Lyne, 2001, "On-Farm Evaluation of Diesel Fuel Oxygenated with Ethanol," American Society of Agricultural Engineers (ASAE) paper no. 01-6173, presented at 2001 ASAE Annual International Meeting, Sacramento, CA, July 30-Aug. 1.

Hydrocarbon Processing, 1999, "Hydrocarbon Processing's Petrochemical Processes 1999," March, pp.92-96.

Hydrocarbon Processing, 2001, "Hydrocarbon Processing's Petrochemical Processes 2001," March, pp.136.

Intergovernmental Panel on Climate Change (IPCC), 1996, Revised IPCC Guidelines for National Greenhouse Gas Inventories: Workbook, London, U.K., p.2.15-2.16.

Intergovernmental Panel on Climate Change (IPCC), 2001, Climate Change 2001: Impacts, Adaptation, and Vulnerability, London, U.K.

Kaiser, E-A. and O. Heinemeyer, 1996, "Temporal Changes in $\mathrm{N}_{2} \mathrm{O}$-Losses from Two Arable Soils," Plant and Soil 181: 57-63.

Levelton Engineering Ltd., (S\&T) ${ }^{2}$ Consulting, Inc., and J.E. and Associates, 1999, Assessment of Net Emissions of Greenhouse Gases from Ethanol-Gasoline Blends in South Ontario, prepared for Agriculture and Agro-Food Canada, Ottawa, Canada, August 30.

Marek, N., and J. Evanoff, 2001, "The Use of Ethanol Blended Diesel Fuel in Unmodified Compression-Ignition Engines: an Interim Case Study," paper no. 287, Proceedings of the $94^{\text {th }}$ Annual Conference and Exhibition of the Air and Waste Management Association, Orlando, FL, June 24-28.

Peeples, J., and I. MacMillan, 2001, "O²DieselTM Technical \& Market Summary," presented at U.S. Department of Energy/National Renewable Energy Laboratory E-Diesel Status Workshop, Chicago, IL, Oct. 9.

Shapouri, H., J.A. Duffield, and M. Wang, 2002, The Energy Balance of Corn Ethanol: An Update, Agricultural Economic Report No. 814, United States Department of Agriculture, Office of the Chief Economist, Office of Energy Policy and New Uses, Washington, D.C., July. 
Shaw, M., 2002, personal communication, Renewable Fuels Association, Washington, D.C., Dec. 11.

Silgram, M., R. Waring, S. Anthony, and J. Webb, 2001, "Intercomparison of National and IPCC Methods for Estimating N Loss from Agricultural Land," Nutrient Cycling in Agroecosystems 60: 189-195.

Taylor, H., 2002, personal communication, U.S. Department of Agriculture, Economic Research Service, April 4.

The Fertilizer Institute (TFI), 2001, Production Cost Surveys for the Year Ending December 31, 2000, compiled by International Fertilizer Development Center, Muscle Shoals, AL, for TFI, Washington, D.C., May.

U.S. Department of Energy (DOE), 2000, Chemical Industry of the Future, Energy and Environmental Profile of the U.S. Chemical Industry, Office of Industrial Technologies, Washington, D.C., May.

U.S. Environmental Protection Agency (EPA), 1991, Nonroad Engine and Vehicle Emission Study (NEVES) Report, EPA 460/3-91-02, National Vehicle and Fuel Emission Laboratory, Office of Air and Radiation, U.S. Environmental Protection Agency, Washington, D.C., Nov.

U.S. Environmental Protection Agency (EPA), 2002a, The EPA's Non-Road Emission Model, Accessible for downloading at http://www.epa.gov/otaq/nonrdmdl.htm.

U.S. Environmental Protection Agency (EPA), 2002b User's Guide to MOBILE6.0 Mobile Source Emission Factor Model, EPA420-R-02-001, Office of Transportation and Air Quality, Ann Arbor, MI, Jan.

Wang, M.Q., 1996, Development and Use of the GREET Model to Estimate Fuel-Cycle Energy Use and Emissions of Various Transportation Technologies and Fuels, ANL/ESD-31, Center for Transportation Research, Argonne National Laboratory, Argonne, IL, June.

Wang, M., C. Saricks, and M. Wu, 1997, Fuel-Cycle Fossil Energy Use and Greenhouse Gas Emissions of Fuel Ethanol Produced from U.S. Midwest Corn, prepared for the Illinois Department of Commerce and Community Affairs, by the Center for Transportation Research, Argonne National Laboratory, Argonne, IL, Dec.

Wang, M.Q., 1999, GREET 1.5 - Transportation Fuel-Cycle Model, Volume 1: Methodology, Development, Use, and Results, ANL/ESD-39, Center for Transportation Research, Argonne National Laboratory, Argonne, IL, Aug.

Wang, M.Q., C. Saricks, and D. Santini, 1999, Effects of Fuel Ethanol Use on Fuel-Cycle Energy and Greenhouse Gas Emissions, ANL/ESD-38, Center for Transportation Research, Argonne National Laboratory, Argonne, IL, Jan.

Wang, M.Q., 2001, Development and Use of GREET 1.6 Fuel-Cycle Model for Transportation Fuels and Vehicle Technologies, ANL/ESD/TM-163, Center for Transportation Research, Argonne National Laboratory, June. 


\section{Appendix A: Energy Use and Emissions of Fertilizer Production}

Energy use and emissions data for fertilizer production were obtained from a report by the U.S. Department of Energy (DOE 2000), from publications by the European Fertilizer Manufacturers Association (EFMA 1995; 2000a, b, c, d), and from the annual survey by The Fertilizer Institute (TFI 2001). The DOE report provides relatively complete data on energy use and emission factors. Neither the DOE report nor subsequent communications with Energetics, the report contractor, could confirm whether lower or higher heating values were used. It appears that no uniform set of values was applied in the DOE report. In most cases, DOE did not present information on the amount of feedstocks used for fertilizer production. The EFMA publications provide a more detailed description of fertilizer production processes, but data on feedstock use, process energy consumption, and emissions are not complete. However, EFMA explicitly states that LHVs were used in its publications. The TFI survey provides fuel and electricity use for fertilizer production. Because NG is both a feedstock and a fuel in the production of ammonia fertilizer, DOE and TFI provided only aggregate (not allocated) NG use for ammonia production.

Production of ammonium nitrate and urea requires the use of ammonia as the major feedstock. It is therefore necessary to include process energy and emissions associated with ammonia production in estimating the energy use and emissions of these nitrogen fertilizers.

\section{Data Sources}

Table A1 presents energy and emission data for ammonia production, Table A2 for urea production, Table A3 for nitric acid production, Table A4 for ammonium nitrate production, Table A5 for sulfuric acid production, Table A6 for phosphoric rock production, and Table A7 for phosphoric acid production. In these tables, blank cells mean that no data were available from a given study. 
Table A1. Feedstock Use, Energy Use and Emissions for Ammonia Production (per ton of ammonia produced)

\begin{tabular}{|c|c|c|c|c|c|c|}
\hline & $\begin{array}{l}\text { DOE } \\
(\mathbf{2 0 0 0 )}\end{array}$ & $\begin{array}{l}\text { EFMA } \\
(2000 a)\end{array}$ & $\begin{array}{c}\text { TFI } \\
(2001)\end{array}$ & $\begin{array}{l}\text { Krupp } \\
\text { Uhde }^{\mathrm{c}}\end{array}$ & Synetix ${ }^{c, d}$ & $\begin{array}{c}\text { Kellogg, } \\
\text { Brown\&Root }^{\mathrm{c}, \mathrm{d}}\end{array}$ \\
\hline \multicolumn{7}{|l|}{ Feedstock (ton) } \\
\hline NG & $0.46^{\mathrm{a}}$ & 0.463 & $0.46^{\mathrm{a}}$ & $0.46^{\mathrm{a}}$ & $0.46^{\mathrm{a}}$ & $0.46^{\mathrm{a}}$ \\
\hline \multicolumn{7}{|c|}{ Process Energy (mmBtu) } \\
\hline NG and other fuels & 3.556 & $6.193-7.739^{\mathrm{b}}$ & 11.371 & 5.034 & $4.494-6.294$ & $6.094-7.094$ \\
\hline Electricity & 1.838 & & 0.389 & & & \\
\hline Total process fuels & 5.394 & $6.205-7.755$ & 11.760 & 5.034 & $4.494-6.294$ & $6.094-7.094$ \\
\hline \multicolumn{7}{|c|}{ Process-Related Emissions (lb) } \\
\hline $\mathrm{CO}$ & 15.8 & 0.06 & & & & \\
\hline $\mathrm{CO}_{2}$ & 2446.8 & 1000.0 & & & & \\
\hline $\mathrm{NO}_{\mathrm{x}}$ & & 2.0 & & & & \\
\hline TOC & 9.44 & & & & & \\
\hline $\mathrm{SO}_{2}$ & 0.058 & 0.02 & & & & \\
\hline
\end{tabular}

${ }^{\text {a }}$ This value was obtained from mass balance estimates in Brown et al. (1996).

b This value is for ammonia produced by using conventional reforming technology. The EFMA did not separate total process fuel use into NG and electricity. We assumed all the process fuels estimated by the EFMA were NG.

${ }^{\mathrm{c}}$ From Hydrocarbon Processing (1999).

${ }^{\mathrm{d}}$ From Hydrocarbon Processing (2001).

Note that in Table A1, the averaged total NG (and other fuel) consumption value obtained by TFI is significantly higher than the value from other data sources. Assuming that the same amount of NG reported by the other sources was used as a feedstock for ammonia production, a much higher requirement for process fuel can be inferred in the TFI survey. This assumption will significantly affect emissions for the production of other nitrogen fertilizers, when emissions from combustion are accounted for. The TFI data were considered in our high-energy-use case (see Tables 4 and 5 in report). 
Table A2. Feedstock Use, Energy Use, and Emissions of Urea Production (per ton of urea produced)

\begin{tabular}{|l|c|c|c|}
\hline & DOE (2000) & $\begin{array}{c}\text { EFMA } \\
(\mathbf{2 0 0 0 b})\end{array}$ & Snamprogetti $^{\text {c }}$ \\
\hline Feedstock (ton) & 0.57 & 0.566 \\
\hline Ammonia & $0.567^{\mathrm{a}}$ & \multicolumn{3}{|l|}{} \\
\hline Process Energy (mmBtu) & 1.464 & $2.816^{\mathrm{b}}$ & 2.679 \\
\hline NG and other fuels & 0.212 & 0.046 & 0.065 \\
\hline Electricity & 1.676 & 2.862 & 2.744 \\
\hline Total process fuels & 241 & 45 & \\
\hline Process-Related Emissions (lb) & 0.234 & 0.65 & \\
\hline PM (uncontrolled) & \multicolumn{3}{|l}{} \\
\hline PM (controlled) &
\end{tabular}

a This value was based on stoichiometric calculations of mass balance.

b We estimated the process energy use on the basis of the steam consumption value provided in the EFMA (2000b) and steam temperature from the Snamprogetti process.

c From Hydrocarbon Processing (1999).

Table A3. Feedstock Use, Energy Use, and Emissions of Nitric Acid Production (per ton of nitric acid produced)

\begin{tabular}{|c|c|c|}
\hline & DOE (2000) & EFMA (2000c) \\
\hline \multicolumn{3}{|l|}{ Feedstock (ton) } \\
\hline Ammonia & $0.405^{\mathrm{a}}$ & $0.405^{\mathrm{a}}$ \\
\hline \multicolumn{3}{|c|}{ Process Energy (mmBtu) } \\
\hline NG and other fuels & 0.526 & \\
\hline Electricity & 0.006 & \\
\hline Total process fuels & 0.532 & \\
\hline \multicolumn{3}{|c|}{ Process-Related Emissions (lb) } \\
\hline $\mathrm{NO}_{\mathrm{x}}$ (uncontrolled) & 33.5 & 30.12 \\
\hline $\mathrm{NO}_{\mathrm{x}}$ (controlled) & 2.2 & 1.21 \\
\hline $\mathrm{N}_{2} \mathrm{O}$ (uncontrolled) & $11^{\mathrm{b}}$ & $3.63-51.48^{\mathrm{c}}$ \\
\hline
\end{tabular}

a This value was based on stoichiometric calculations of mass balance.

b From IPCC (1996).

c Calculated on the basis of reported concentration of $\mathrm{N}_{2} \mathrm{O}$ in exhaust gases. 
Table A4. Feedstock Use, Energy Use, and Emissions of Ammonium Nitrate Production (per ton of ammonium nitrate produced)

\begin{tabular}{|c|c|}
\hline & DOE (2000) \\
\hline \multicolumn{2}{|l|}{ Feedstock (ton) } \\
\hline Ammonia & $0.213^{\mathrm{a}}$ \\
\hline Nitric acid & $0.788^{\mathrm{a}}$ \\
\hline \multicolumn{2}{|l|}{ Process Energy (mmBtu) } \\
\hline NG and other fuels & 0.440 \\
\hline Electricity & 0.242 \\
\hline Total process fuels & 0.682 \\
\hline \multicolumn{2}{|c|}{ Process-Related Emissions (lb) } \\
\hline PM (uncontrolled) & 528.065 \\
\hline PM (controlled) & 4.662 \\
\hline
\end{tabular}

a These values were based on stoichiometric calculations of mass balance.

Table A5. Feedstock Use, Energy Use, and Emissions of Sulfuric Acid Production (per ton of sulfuric acid produced)

\begin{tabular}{|l|c|c|}
\hline \multicolumn{2}{|l|}{ DOE (2000) } & TFI (2001) \\
\hline \multicolumn{2}{|l|}{ Feedstock (ton) } & 0.325 \\
\hline Sulfur & \\
\hline Process Energy (mmBtu) & 0.029 \\
\hline NG and other fuels & 0.060 & 0.071 \\
\hline Electricity & 0.056 & 0.100 \\
\hline Total process fuels & 0.116 & \\
\hline Process-Related Emissions (lb) & $40^{\mathrm{a}}$ & \\
\hline $\mathrm{SO}_{2}$ &
\end{tabular}

${ }^{\text {a }}$ Based on emissions for the conversion efficiency of $97 \%$ from $\mathrm{SO}_{2}$ to $\mathrm{SO}_{3}$.

Table A6. Energy Use of Phosphoric Rock Production (mmBtu/ton)

\begin{tabular}{|l|c|}
\hline & TFI (2001) \\
\hline NG and other fuels & \\
\hline Electricity & 0.245 \\
\hline Total process fuels & 0.245 \\
\hline
\end{tabular}


Table A7. Feedstock Use and Energy Use of Phosphoric Acid Production (per ton)

\begin{tabular}{|l|c|c|c|}
\hline & DOE (2000) & EFMA (1995) & TFI (2001) \\
\hline Feedstock (ton) & & & 2.674 \\
\hline Sulfuric acid & $2.6-3.5$ & 3.525 \\
\hline Phosphoric rock & & $1.546-6.800^{\mathrm{a}}$ & \\
\hline Process Energy (mmBtu) & 2.972 & $0.371-0.557$ & 0.481 \\
\hline NG and other fuels & 0.650 & $1.917-7.357$ & 0.481 \\
\hline Electricity & 3.622 &
\end{tabular}

a Calculated on the basis of reported steam consumption. Steam was assumed to be at 1 bar and $200^{\circ} \mathrm{C}$. 


\section{Appendix B: Nitrous Oxide Emissions from Nitrogen Fertilizer Applications in Corn Fields}

\section{Current $\mathrm{N}_{2} \mathrm{O}$ Emission Values}

Assumptions in previous GREET versions concerning $\mathrm{N}_{2} \mathrm{O}$ flux from soils under corn cultivation are derived from a review of over 30 publications dating from 1997 and earlier (see Wang et al. 1997). The review concentrated on (1) direct $\mathrm{N}_{2} \mathrm{O}$ emissions from soil and (2) nitrogen bound as $\mathrm{N}_{2} \mathrm{O}$ and converted from leached nitrates in drainage and runoff water by means of microbial denitrification.

In general, the reviewed studies focused on the fate of the nitrogen in applied N-fertilizers over an entire growing season across several different growing regimes. Based on that review, We determined parametric assumptions for calculating $\mathrm{N}_{2} \mathrm{O}$ emissions in cornfields. Table B1 summarizes the resulting values adopted for the GREET model. For comparison, we also show IPCC's corresponding values in the table. Our and IPCC $\mathrm{N}_{2} \mathrm{O}$ emission values differ chiefly in the indirect emissions from nitrate leaching. Data from U.S. cornfields, as reviewed by us, showed a lower leaching rate and much lower conversion rate from nitrate to $\mathrm{N}_{2} \mathrm{O}$. It should be noted that our review focused on U.S. Midwest cornfields, while the IPCC values could be intended to represent agricultural fields for all crops worldwide.

Both our 1997 review and the IPCC study conceded large uncertainties in $\mathrm{N}_{2} \mathrm{O}$ emissions. The sources of uncertainty include the following: (1) lack of uniform control measurement of background $\mathrm{N}_{2} \mathrm{O}$, (2) failure of any single study to measure both direct-to-air $\mathrm{N}_{2} \mathrm{O}$ and $\mathrm{N}_{2} \mathrm{O}$ from leachate, (3) variable nitrate conversion rates and incomplete conversion for surface water and ground water, and (4) varying estimates of $\mathrm{N}_{2} \mathrm{O}$ solubility in water. Because of these underlying factors, uncertainties in $\mathrm{N}_{2} \mathrm{O}$ emissions will continue to exist. 
Table B1. Soil $\mathrm{N}_{2} \mathrm{O}$ Emissions in Agricultural Fields

\begin{tabular}{|c|c|c|}
\hline Item & $\begin{array}{c}\mathrm{N}_{2} \mathrm{O} \text { Emissions: } \\
\text { Range Values (\%) }\end{array}$ & $\begin{array}{l}\mathrm{N}_{2} \mathrm{O} \text { Emissions: } \\
\text { Point Values (\%) }\end{array}$ \\
\hline \multicolumn{3}{|l|}{ Wang et al. 1997 (for U.S. midwest corn fields) } \\
\hline Direct $\mathrm{N}_{2} \mathrm{O}$ air emissions: $\mathrm{N}_{2} \mathrm{O}-\mathrm{N}$ as $\%$ of $\mathrm{N}$ in $\mathrm{N}$-fertilizer & $0-3.15$ & 1.22 \\
\hline $\mathrm{N}$ loss in leached nitrate: nitrate- $\mathrm{N}$ as $\%$ of $\mathrm{N}$ in $\mathrm{N}$-fertilizer & $12-26.6$ & 24 \\
\hline Nitrate to $\mathrm{N}_{2} \mathrm{O}$ conversion: $\mathrm{N}_{2} \mathrm{O}-\mathrm{N}$ as $\%$ of leached nitrate- $\mathrm{N}$ & 1 & 1 \\
\hline Total & & 1.46 \\
\hline \multicolumn{3}{|l|}{ IPCC 1996 (potentially for all crop lands worldwide) } \\
\hline Direct $\mathrm{N}_{2} \mathrm{O}$ air emissions: $\mathrm{N}_{2} \mathrm{O}-\mathrm{N}$ as $\%$ of $\mathrm{N}$ in $\mathrm{N}$-fertilizer & $0.25-2.25$ & 1.25 \\
\hline $\mathrm{N}$ loss in leached nitrate: nitrate- $\mathrm{N}$ as $\%$ of $\mathrm{N}$ in $\mathrm{N}$-fertilizer & 30 & 30 \\
\hline Nitrate to $\mathrm{N}_{2} \mathrm{O}$ conversion: $\mathrm{N}_{2} \mathrm{O}-\mathrm{N}$ as $\%$ of leached nitrate- $\mathrm{N}$ & $0.2-12$ & 2.5 \\
\hline Gasification of N-fertilizer to $\mathrm{NO}_{x}$ and $\mathrm{NH}_{3}$ & 10 & 10 \\
\hline $\mathrm{N}_{2} \mathrm{O}-\mathrm{N}$ from gasified $\mathrm{NO}_{\mathrm{x}}$ and $\mathrm{NH}_{3}$ & $0.2-2$ & 1 \\
\hline Total & & 2.1 \\
\hline
\end{tabular}

\section{Additional Issues Regarding $\mathrm{N}_{2} \mathrm{O}$ Emissions}

The studies reviewed for our 1997 analysis did not explicitly address $\mathrm{N}_{2} \mathrm{O}$ flux behavior outside of the growing season. Recent investigations of off-season $\mathrm{N}_{2} \mathrm{O}$ flux have indicated that significant $\mathrm{N}_{2} \mathrm{O}$ emissions can occur during freeze/thaw cycles in winter and early spring (preplanting). Kaiser and Heinemeyer (1996) reported the results of a two-year study of sandy and silty loam crop soils in Germany that identified peak rates of $\mathrm{N}_{2} \mathrm{O}$ emission at (1) spring thaw and (2) within one week after $\mathrm{N}$-fertilizer application. Emission intensity was approximately equal during both types of episodes. Flessa and Dorsch (1995) reported that the highest $\mathrm{N}_{2} \mathrm{O}$ release rates measured during their experiments with wheat-growing soils in southern Germany occurred during January-February thaws. However, Flessa and Dorsch pointed out that "high $\mathrm{N}_{2} \mathrm{O}$ fluxes may occur from cultivated soils even if no mineral $\mathrm{N}$-fertilizer is applied." This could imply that significant $\mathrm{N}_{2} \mathrm{O}$ releases are caused by factors, other than $\mathrm{N}$-fertilizer applications, that occur during freeze/thaw cycles.

Table B1 shows a large discrepancy in estimates of indirect $\mathrm{N}$ as $\mathrm{N}_{2} \mathrm{O}$ emissions due to denitrification. While GREET shows an $\mathrm{N}_{2} \mathrm{O}$ emission rate of $0.24 \%$, IPCC shows a rate of $0.75 \%$. A recent detailed study on nitrate-to- $\mathrm{N}_{2} \mathrm{O}$ emissions in the United Kingdom (Silgram et al., 2001) indicated that the IPCC might have overestimated the indirect $\mathrm{N}_{2} \mathrm{O}$ emissions by a large margin. With detailed soil simulations in the United Kingdom, the authors concluded that IPCC's estimates are 2.25 times higher than U.K. estimates, even though the authors used the IPCC conversion factor of $2.5 \%$ from nitrate to $\mathrm{N}_{2} \mathrm{O}$. If the IPCC conversion rate is adjusted with the U.K. results, the indirect $\mathrm{N}_{2} \mathrm{O}$ emission rate would be $0.33 \%(0.75 \% \div 2.25)$.

Another source of $\mathrm{N}_{2} \mathrm{O}$ emissions from agricultural fields, one that we did not include, is crop residues. IPCC (1996) maintained that $0.015 \mathrm{~kg}$ of $\mathrm{N}$ is produced in the soil per $\mathrm{kg}$ of dry biomass left in the field. We use corn as an example to demonstrate the magnitude of nitrogen from crop residues. Assuming the yield ratio of corn kernels to corn stover to be 1 to 1 on a dry- 
mass basis, harvesting a bushel of corn could result in production of $21 \mathrm{~kg}$ (the dry weight of a bushel of corn) of dry corn stover. This will result in $0.315 \mathrm{~kg}$ of nitrogen in the soil per bushel of corn harvested $(0.015 \times 21)$. On the other hand, the N-fertilizer application rate for U.S. corn farming is about $0.47 \mathrm{~kg} \mathrm{~N}$-fertilizer per bushel of corn (see Table 6). Thus, the amount of nitrogen to soil from corn residues is about $2 / 3$ of that from $\mathrm{N}$-fertilizer applications. However, emissions from the nitrogen in biomass should already be taken into account with measured $\mathrm{N}_{2} \mathrm{O}$ emissions from cornfields when crop residues are not removed from fields, as is the case for most U.S. corn farms.

\section{Parametric Assumptions for GREET Simulations}

Considering the potential $\mathrm{N}$-fertilizer-induced $\mathrm{N}_{2} \mathrm{O}$ emissions outside of growing seasons and a small increase in indirect $\mathrm{N}_{2} \mathrm{O}$ emissions from nitrate, we have increased $\mathrm{N}_{2} \mathrm{O}$ emissions for our new "point estimate" from $1.5 \%$ to $2.0 \%$, with a range of $1 \%$ to $3 \%$. 